\title{
The Intrinsic Enzyme Activities of the Classic Polyoxometalates
}

\author{
Boyu Zhang, Mingming Zhao, Yanfei Qi', Rui Tian, Boye B. Carter, Hangjin Zou, \\ Chuhan Zhang \& Chunyan Wang
}

The mimicking enzyme activities of eighteen classic POMs with different structures, Keggin $\left(\mathrm{H}_{3} \mathrm{PW}_{12} \mathrm{O}_{40}, \mathrm{H}_{4} \mathrm{SiW}_{12} \mathrm{O}_{40}, \mathrm{H}_{4} \mathrm{GeW}_{12} \mathrm{O}_{40}, \mathrm{~K}_{4} \mathrm{GeW}_{12} \mathrm{O}_{40}, \mathrm{H}_{3} \mathrm{PMo}_{12} \mathrm{O}_{40}, \mathrm{H}_{4} \mathrm{SiMo}_{12} \mathrm{O}_{40}\right.$ and $\left.\mathrm{EU}_{3} \mathrm{PMO}_{12} \mathrm{O}_{40}\right)$, Wells-Dawson $\left(\mathrm{H}_{6} \mathrm{P}_{2} \mathrm{Mo}_{18} \mathrm{O}_{62}, \alpha-\left(\mathrm{NH}_{4}\right)_{6} \mathrm{P}_{2} \mathrm{~W}_{18} \mathrm{O}_{62}\right.$ and $\left.\alpha-\mathrm{K}_{6} \mathrm{P}_{2} \mathrm{~W}_{18} \mathrm{O}_{62} \cdot 14 \mathrm{H}_{2} \mathrm{O}\right)$, lacunary-Keggin $\left(\mathrm{Na}_{8} \mathrm{H}[\alpha-\right.$ $\left.\mathrm{PW}_{9} \mathrm{O}_{34}\right], \mathrm{Na}_{10}\left[\alpha-\mathrm{SiW}_{9} \mathrm{O}_{34}\right], \mathrm{Na}_{10}\left[\alpha-\mathrm{GeW}_{9} \mathrm{O}_{34}\right]$ and $\mathrm{K}_{8}\left[\gamma-\mathrm{SiW}_{10} \mathrm{O}_{36}\right]$ ), the transition-metal substitutedtype $\left(\alpha-1,2,3-\mathrm{K}_{6} \mathrm{H}\left[\mathrm{SiW}_{9} \mathrm{~V}_{3} \mathrm{O}_{34}\right]\right.$ and $\left.\mathrm{H}_{5} \mathrm{PMo}_{10} \mathrm{~V}_{2} \mathrm{O}_{40}\right)$, sandwich-type $\left(\mathrm{K}_{10} \mathrm{P}_{2} \mathrm{~W}_{18} \mathrm{Fe}_{4}\left(\mathrm{H}_{2} \mathrm{O}\right)_{2} \mathrm{O}_{68}\right)$ and an isopolyoxotungstate $\left(\mathrm{Na}_{10} \mathrm{H}_{2} \mathrm{~W}_{12} \mathrm{O}_{42}\right)$ were screened and compared. The mechanisms and reaction conditions of $\mathrm{POMs}$ with mimicking enzyme-like activities were also analyzed. The results shown that the structures, the hybrid atoms, the coordination atoms, the substituted metal atoms, $\mathrm{pH}$ and substrate are the effect factors for the enzyme mimic activities of POM. Among the eighteen POMs, $\mathrm{H}_{3} \mathrm{PW}_{12} \mathrm{O}_{40}, \mathrm{H}_{4} \mathrm{SiW}_{12} \mathrm{O}_{40}, \mathrm{H}_{4} \mathrm{GeW}_{12} \mathrm{O}_{40}, \alpha-\left(\mathrm{NH}_{4}\right)_{6} \mathrm{P}_{2} \mathrm{~W}_{18} \mathrm{O}_{62}, \alpha-\mathrm{K}_{6} \mathrm{P}_{2} \mathrm{~W}_{18} \mathrm{O}_{62} \cdot 14 \mathrm{H}_{2} \mathrm{O}, \mathrm{Na} \mathrm{H}_{8}\left[\alpha-\mathrm{PW}_{9} \mathrm{O}_{34}\right]$, $\mathrm{Na}_{10}\left[\alpha-\mathrm{SiW}_{9} \mathrm{O}_{34}\right], \mathrm{Na}_{10}\left[\alpha-\mathrm{GeW}_{9} \mathrm{O}_{34}\right], \mathrm{K}_{8}\left[\gamma-\mathrm{SiW}_{10} \mathrm{O}_{36}\right], \mathrm{K}_{10} \mathrm{P}_{2} \mathrm{~W}_{18} \mathrm{Fe}_{4}\left(\mathrm{H}_{2} \mathrm{O}\right)_{2} \mathrm{O}_{68}$ and $\mathrm{Na}_{10} \mathrm{H}_{2} \mathrm{~W}_{12} \mathrm{O}_{42}$ had the peroxidase activities. $\mathrm{Eu}_{3} \mathrm{PMo}_{12} \mathrm{O}_{40}, \mathrm{H}_{3} \mathrm{PMo}_{12} \mathrm{O}_{40}, \mathrm{H}_{4} \mathrm{SiMo}_{12} \mathrm{O}_{40}, \alpha-1,2,3-\mathrm{K}_{6} \mathrm{H}\left[\mathrm{SiW}_{9} \mathrm{~V}_{3} \mathrm{O}_{34}\right], \mathrm{H}_{6} \mathrm{P}_{2} \mathrm{Mo}_{18} \mathrm{O}_{62}$ and $\mathrm{H}_{5} \mathrm{PMo}_{10} \mathrm{~V}_{2} \mathrm{O}_{40}$ showed the oxidase-like activities. $\mathrm{K}_{4} \mathrm{GeW}_{12} \mathrm{O}_{40}$ did not show the peroxidase and oxidase activities. The $\mathrm{Na}_{8} \mathrm{H}\left[\alpha-\mathrm{PW}_{9} \mathrm{O}_{34}\right], \mathrm{Na}_{10}\left[\alpha-\mathrm{SiW}_{9} \mathrm{O}_{34}\right]$ and $\mathrm{Na}_{10}\left[\alpha-\mathrm{GeW}_{9} \mathrm{O}_{34}\right]$ showed intrinsic enzyme activities at alkaline conditions, which were different from other type of $\mathrm{POMs}$. The sandwichtype $\mathrm{K}_{10} \mathrm{P}_{2} \mathrm{~W}_{18} \mathrm{Fe}_{4}\left(\mathrm{H}_{2} \mathrm{O}\right)_{2} \mathrm{O}_{68}$ displayed the strongest peroxidase activity, which is similar to natural horseradish peroxidase.

Natural enzymes with high substrate specificity, activities and yields have attracted continuous scientific research interest. However, their intrinsic drawbacks, such as poor substrate versatility and assortment, low operational stabilities and low tolerance to environment conditions, limited their applications ${ }^{1,2}$. Therefore, artificial enzymes, as highly stable and low-cost alternatives to nature enzymes, attract continuing attention ${ }^{3,4}$. Constructing and screening highly efficient enzyme mimics is a tremendous motivator for researchers. To date, impressive development has been made in the field of artificial enzymes, and numerous diversity materials, such as supramolecular, porphyrins, nanoenzyme, and metal complexes have been extensively explored to mimic natural enzymes ${ }^{5-9}$. Generally, the efforts toward designing artificial enzymes with high activity can be divided in to two groups: the first is 'structural mimicking', which is to mimic the structure of enzymes, and the second is 'functional mimicking', which is to mimic enzymes that have similar activities ${ }^{10}$. Functional mimicking offers a straight forward method to discover new properties of functional materials, such as the discovery of nanoparticles with peroxidase-like activity, later referred to as nanozymes ${ }^{9,11}$.

Polyoxometalates (POMs), a metal oxide cluster compounds, are combinations between oxygen and early transition metals at their high oxidation states ${ }^{12,13}$. The majority of the applications of POMs are found in the area of catalysis ${ }^{14-16}$. It is reported that POMs can catalyze $\mathrm{H}_{2} \mathrm{O}_{2}$-based epoxidation and oxidation of organic substrates by $\mathrm{O}_{2}$ and $\mathrm{H}_{2} \mathrm{O}_{2}$ by multistep electron-transfer processes ${ }^{17-19}$. Therefore, it is not astonishing that POMs can used as enzyme mimics to catalyze $\mathrm{H}_{2} \mathrm{O}_{2}$-based oxidation of $3,3^{\prime}, 5,5^{\prime}$-tetramethylbenzidine (TMB) and Ortho-Phenylenediamine (OPD) to a colored complex which can be applied in bio- and chem-sensing, i.e., colorimetric detection of tumor cells and glucose. Wang et al. firstly found that folate-functionalized polyoxometalate nanoparticles have unique oxidase-like activity in colorimetric multiplexed immunoassay ${ }^{20}$. Moreover, they investigated the peroxidase mimetics of POMs $\left(\mathrm{H}_{3} \mathrm{PW}_{12} \mathrm{O}_{40}, \mathrm{H}_{4} \mathrm{SiW}_{12} \mathrm{O}_{40}\right.$ and $\left.\mathrm{H}_{3} \mathrm{PMo}_{12} \mathrm{O}_{40}\right)$ and $\mathrm{H}_{3} \mathrm{PW}_{12} \mathrm{O}_{40} /$ graphene in detection of glucose and $\mathrm{H}_{2} \mathrm{O}_{2}{ }^{21}$. Meanwhile, Sun et al. reported a simple, fast and sensitive colorimetric method to detect $\mathrm{H}_{2} \mathrm{O}_{2}$ based on $\mathrm{H}_{4} \mathrm{SiW}_{12} \mathrm{O}_{40}{ }^{19}$. Furthermore, Wang et al. synthesized folate-functionalized POM hybrid nanoparticles $\left(F A-g-\left[\left(\mathrm{FeOH}_{2}\right)_{2} \mathrm{SiW}_{10} \mathrm{O}_{36}\right]\right.$ and $\mathrm{FA}_{\mathrm{n}} \mathrm{PMo}_{12-\mathrm{n}} \mathrm{V}_{\mathrm{n}} \mathrm{O}_{40}, \mathrm{n}=1-3$ ) and studied the peroxidase-like activity in colorimetric assay of $\mathrm{H}_{2} \mathrm{O}_{2}$ and cancer cells ${ }^{22}$. These above early findings proved that the typical polyoxometalates and their hybrid nanoparticles have the enzyme mimics activities. 

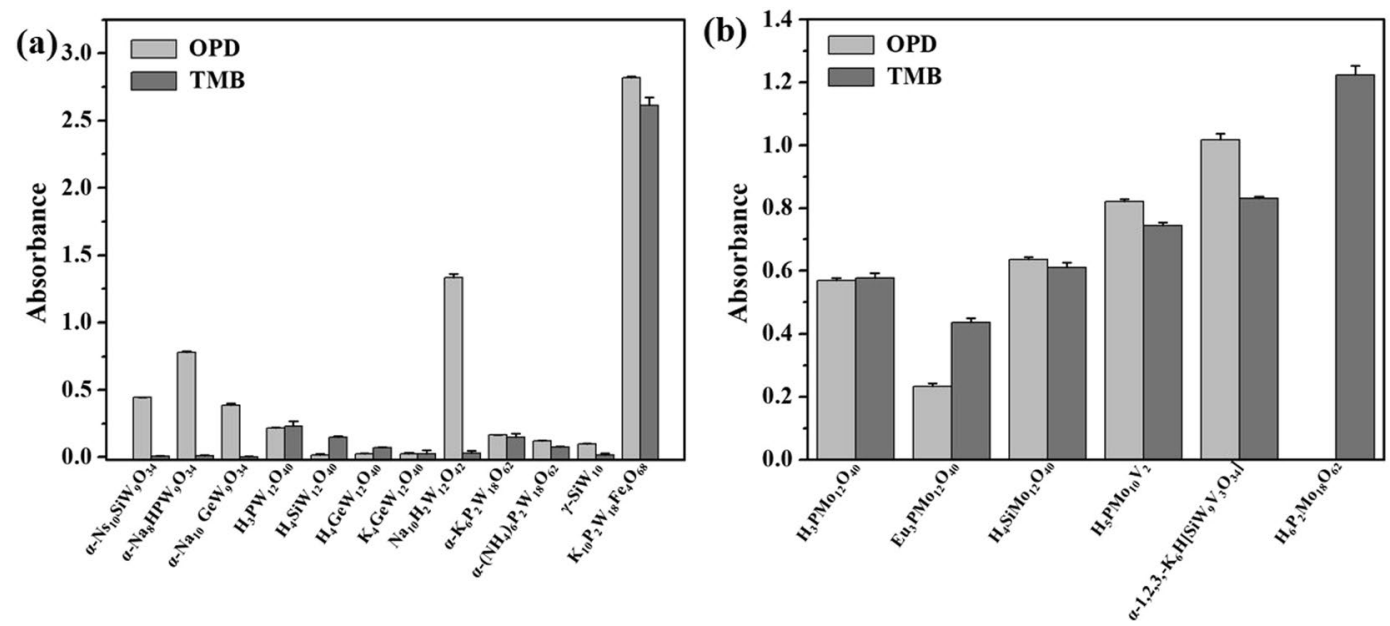

Figure 1. Comparison of enzyme mimic activities of polyoxometalates. (a) peroxidase-like activities with TMB or OPD as substrate. (b) oxidase-like activities with TMB or OPD as substrate. Conditions: $200 \mu \mathrm{M}$ POMs, $200 \mathrm{mM} \mathrm{H}_{2} \mathrm{O}_{2}$ at room temperature for 10 minutes in the optimum $\mathrm{pH}$.

POMs with different structural morphologies can incorporated with different metal atoms. The new inorganic compositions have presented attractive enzyme mimic features. For example, Li et al. synthesized three new tetra-nuclear $\mathrm{Zr}^{\mathrm{IV}}$ - substituted POMs, which exhibit peroxidase-like activities ${ }^{23}$. Wang et al. established a colorimetric detection method based on the metal-substituted polyoxometalates of $\mathrm{SiW}_{9} \mathrm{M}_{3}\left(\mathrm{M}=\mathrm{Co}^{2+}, \mathrm{Fe}^{3+}, \mathrm{Cu}^{2+}\right.$ and $\left.\mathrm{Mn}^{2+}\right)^{24}$. Xu et al. developed a Fe-containing heteropolyacid by cation-exchange and employed $\mathrm{KFePW}_{12} \mathrm{O}_{40}$ nanostructures for Fenton, photo-Fenton and enzyme-mimetic reactions ${ }^{25}$.

POMs can assemble with functional materials to improve their properties and potential practical applications $^{26}$. For instance, the dipeptide-POMs-graphene oxide ternary hybrid prepared by a precipitation method show a higher peroxidase activity compared to POMs alone ${ }^{27}$. Inorganic-organic hybrids based on POMs and transition-metal complexes are another similar strategy to construct new enzyme mimics. Gao et al. synthesized and structurally characterized two new hybrids based on copper(II)-imidazole complex modified sandwich-type tungstobismuthate or tungstoantimonite, $\mathrm{Na}_{4} \mathrm{H}_{2}\left[\mathrm{Cu}_{4}\left(\mathrm{H}_{4} \mathrm{im}\right)_{12}\left(\mathrm{H}_{3} \mathrm{im}\right)_{2}\right]\left[\mathrm{Cu}_{3}\left(\mathrm{H}_{2} \mathrm{O}\right)_{3}\left(\mathrm{XW}_{9} \mathrm{O}_{33}\right)_{2}\right] \cdot \mathrm{nH}_{2} \mathrm{O}$ $\left(\mathrm{H}_{4} \mathrm{im}=\right.$ imidazole, $\mathrm{H}_{3} \mathrm{im}=$ deprotonated imidazole, $\left.\mathrm{X}=\mathrm{Bi}, \mathrm{Sb}\right)$, which demonstrate higher peroxidase-like activity than Keggin-type POMs around physiological $\mathrm{pH}$ values in a heterogeneous phase $\mathrm{e}^{28}$. Sha et al. isolated two new POM involved hybrids containing helix/nanocages $\left(\left[\mathrm{Cu}_{2}^{\mathrm{I}} \mathrm{Cu}_{2}^{\mathrm{II}}(\mathrm{fkz})_{2}\left(\mathrm{H}_{2} \mathrm{O}\right)_{7}\left(\mathrm{SiW}_{12} \mathrm{O}_{40}\right)\right]\right.$ and $\left.\left[(\mathrm{Hfkz})_{3}\left(\mathrm{H}_{4} \mathrm{SiW}_{12} \mathrm{O}_{40}\right)\right]\right)$ and systematically studied their peroxidase-like activities ${ }^{29}$. Rao et al. investigated the enzyme mimetic activity of a new inorganic-organic covalent hybrid of POM-calixarene ${ }^{30}$. Wei et al. reported the improved peroxidase-mimic property of the vesicles of hexavanadate-organic hybrid surfactants ${ }^{31}$. Metal-organic framework (MOF) based bio-sensing is a new interesting field. Pillar-layered MOFs have been proven to be an effective route to construct enzyme mimics with high stability and multifunction. The advancement of MOF structure is also help in design of new enzymes with POMs moiety. For example, Qin et al. report a novel efficient peroxidase mimic POM-pillared MOF, $\mathrm{Cu}_{6}(\mathrm{Trz})_{10}\left(\mathrm{H}_{2} \mathrm{O}\right)_{4}\left[\mathrm{H}_{2} \mathrm{SiW}_{12} \mathrm{O}_{40}\right] \cdot 8 \mathrm{H}_{2} \mathrm{O}^{32}$. Recently, Sha et al. reported a stable peroxidase mimic POM-pillared metal-MOF with 6-nuclear $\mathrm{Cu}$-pz and 10-nuclear $\mathrm{Cu}-\mathrm{pz}-\mathrm{Cl}$ cycles, $\left[\mathrm{Cu}_{5}(\mathrm{pz})_{6} \mathrm{Cl}\right]\left[\mathrm{SiW}_{12} \mathrm{O}_{40}\right]^{33}$.

Most of the POMs are stable and show higher enzyme activities at acid condition (about pH value 3 or 4). However, in the physiological solutions ( $\mathrm{pH}$ 7.0-7.5), for most bioanalytical applications, the POM nanozymes become catalytically inactive. Fortunately, POMs show a great diversity in its structure derived from its multiple oxidation states and coordination geometries ${ }^{30,34}$. These features make it much easier to control the size, shape, and charge distribution at the molecular level. Flexibility in the structure makes it possible to fine-tune the redox potentials, acidities, and enzyme activities of POMs. For example, the trivacant Keggin $\mathrm{Na}_{10}\left[\alpha-\mathrm{SiW}_{9} \mathrm{O}_{34}\right]$ exhibits unusual peroxidase-like activity at basic condition ${ }^{35}$. Therefore, it is necessary to systematic investigate of POMs mimic enzymes activity with different structure category. Herein, the mimicking enzyme activities of classic polyoxometalates with different classic structures and different element atoms were screened and compared.

\section{Results and Discussion}

Characterization of POMs. The POMs were prepared according to the literature and identified by FI-IR spectra, UV-Vis spectra, as shown in Supplementary Figs S1 and S2.

Enzyme mimetic activities of POMs. As shown in Fig. 1, the enzyme mimetic activities of 18 POMs with Keggin structures $\left(\mathrm{H}_{3} \mathrm{PW}_{12} \mathrm{O}_{40}, \mathrm{H}_{4} \mathrm{SiW}_{12} \mathrm{O}_{40}, \mathrm{H}_{4} \mathrm{GeW}_{12} \mathrm{O}_{40}, \mathrm{~K}_{4} \mathrm{GeW}_{12} \mathrm{O}_{40}, \mathrm{H}_{3} \mathrm{PMo}_{12} \mathrm{O}_{40}, \mathrm{H}_{4} \mathrm{SiMo}_{12} \mathrm{O}_{40}\right.$ and $\left.\mathrm{Eu}_{3} \mathrm{PMo}_{12} \mathrm{O}_{40}\right)$, Dawson structures $\left(\mathrm{H}_{6} \mathrm{P}_{2} \mathrm{Mo}_{18} \mathrm{O}_{62}, \alpha-\left(\mathrm{NH}_{4}\right)_{6} \mathrm{P}_{2} \mathrm{~W}_{18} \mathrm{O}_{62}\right.$ and $\left.\alpha-\mathrm{K}_{6} \mathrm{P}_{2} \mathrm{~W}_{18} \mathrm{O}_{62} \cdot 14 \mathrm{H}_{2} \mathrm{O}\right)$, lacunary-Keggin structures $\left(\mathrm{Na}_{8} \mathrm{H}\left[\alpha-\mathrm{PW}_{9} \mathrm{O}_{34}\right], \mathrm{Na}_{10}\left[\alpha-\mathrm{SiW}_{9} \mathrm{O}_{34}\right], \mathrm{Na}_{10}\left[\alpha-\mathrm{GeW}_{9} \mathrm{O}_{34}\right]\right.$ and $\left.\mathrm{K}_{8}\left[\gamma-\mathrm{SiW}_{10} \mathrm{O}_{36}\right]\right)$, the transition-metal substituted-type structures $\left(\alpha-1,2,3-\mathrm{K}_{6} \mathrm{H}\left[\mathrm{SiW}_{9} \mathrm{~V}_{3} \mathrm{O}_{34}\right], \mathrm{H}_{5} \mathrm{PMo}_{10} \mathrm{~V}_{2} \mathrm{O}_{40}\right)$ and sandwich-type $\left.\mathrm{K}_{10} \mathrm{P}_{2} \mathrm{~W}_{18} \mathrm{Fe}_{4}\left(\mathrm{H}_{2} \mathrm{O}\right)_{2} \mathrm{O}_{68}\right)$ were studied and compared at the same concentration with OPD and TMB as substrates. It was found that the coordination atoms, Mo and $\mathrm{W}$, have effect on the enzyme mimic activity. All the 
polyoxotungstates $\mathrm{H}_{3} \mathrm{PW}_{12} \mathrm{O}_{40}, \mathrm{H}_{4} \mathrm{SiW}_{12} \mathrm{O}_{40}, \mathrm{H}_{4} \mathrm{GeW}_{12} \mathrm{O}_{40}, \mathrm{~K}_{4} \mathrm{GeW}_{12} \mathrm{O}_{40}, \mathrm{Na}_{10}\left[\alpha-\mathrm{GeW}_{9} \mathrm{O}_{34}\right], \mathrm{Na}_{8} \mathrm{H}\left[\alpha-\mathrm{PW}_{9} \mathrm{O}_{34}\right]$, $\mathrm{Na}_{10}\left[\alpha-\mathrm{SiW}_{9} \mathrm{O}_{34}\right], \mathrm{K}_{8}\left[\gamma-\mathrm{SiW}_{10} \mathrm{O}_{36}\right], \alpha-\left(\mathrm{NH}_{4}\right)_{6} \mathrm{P}_{2} \mathrm{~W}_{18} \mathrm{O}_{62}, \alpha-\mathrm{K}_{6} \mathrm{P}_{2} \mathrm{~W}_{18} \mathrm{O}_{62} \cdot 14 \mathrm{H}_{2} \mathrm{O}, \mathrm{Na}_{10} \mathrm{H}_{2} \mathrm{~W}_{12} \mathrm{O}_{42}$ and $\mathrm{K}_{10} \mathrm{P}_{2} \mathrm{~W}_{18} \mathrm{Fe}_{4}\left(\mathrm{H}_{2} \mathrm{O}\right)_{2} \mathrm{O}_{68}$ are capable of catalyzing typical peroxidase reactions using both chromogenic hemeperoxidase substrates TMB and OPD in the presence of $\mathrm{H}_{2} \mathrm{O}_{2}$ to produce a blue color (maximum absorbance $650 \mathrm{~nm}$ ) and brown color (maximum absorbance $450 \mathrm{~nm}$ ) reaction, respectively, as shown in Fig. 1a. Initially, these reactions were carried out by adding $200 \mu \mathrm{M}$ of POMs with the substrates OPD $(576 \mu \mathrm{M})$ and $\mathrm{H}_{2} \mathrm{O}_{2}(200 \mathrm{mM})$ at room temperature in a buffered solution. It indicates that these POMs have intrinsic peroxidase-like activities towards these substrates (Fig. 1). However, the peroxidase-like activities of these POMs are different in the present of different substrates at the same concentration. For TMB as organic substrate, the absorption values of $\mathrm{TMB}^{+}$indicated that the order of peroxidase-like activities from high to low was $\mathrm{K}_{10} \mathrm{P}_{2} \mathrm{~W}_{18} \mathrm{Fe}_{4}\left(\mathrm{H}_{2} \mathrm{O}\right)_{2} \mathrm{O}_{68}>\mathrm{H}_{3} \mathrm{PW}_{12} \mathrm{O}_{40}>\mathrm{H}_{4} \mathrm{SiW}_{12} \mathrm{O}_{40}>\alpha-\mathrm{K}_{6} \mathrm{P}_{2} \mathrm{~W}_{18} \mathrm{O}_{62} \cdot 14 \mathrm{H}_{2} \mathrm{O}>\alpha-\left(\mathrm{NH}_{4}\right)_{6} \mathrm{P}_{2} \mathrm{~W}_{18} \mathrm{O}_{62}>\mathrm{H}_{4} \mathrm{GeW}_{12^{-}}$ $\mathrm{O}_{40}>\mathrm{Na}_{10} \mathrm{H}_{2} \mathrm{~W}_{12} \mathrm{O}_{42}>\mathrm{K}_{4} \mathrm{GeW}_{12} \mathrm{O}_{40}>\mathrm{K}_{8}\left[\gamma-\mathrm{SiW}_{10} \mathrm{O}_{36}\right]>\mathrm{Na}_{8} \mathrm{H}\left[\alpha-\mathrm{PW}_{9} \mathrm{O}_{34}\right] \approx \mathrm{Na}_{10}\left[\alpha-\mathrm{SiW}_{9} \mathrm{O}_{34}\right] \approx$ $\mathrm{Na}_{10}\left[\alpha-\mathrm{GeW}_{9} \mathrm{O}_{34}\right]$. For OPD as organic substrate, the order of peroxidase-like activities from high to low was $\mathrm{K}_{10} \mathrm{P}_{2} \mathrm{~W}_{18} \mathrm{Fe}_{4}\left(\mathrm{H}_{2} \mathrm{O}\right)_{2} \mathrm{O}_{68}>\mathrm{Na}_{10} \mathrm{H}_{2} \mathrm{~W}_{12} \mathrm{O}_{42}>\mathrm{Na}_{8} \mathrm{H}\left[\alpha-\mathrm{PW}_{9} \mathrm{O}_{34}\right]>\mathrm{Na}_{10}\left[\alpha-\mathrm{SiW}_{9} \mathrm{O}_{34}\right]>\mathrm{Na}_{10}\left[\alpha-\mathrm{GeW}_{9} \mathrm{O}_{34}\right]>\mathrm{H}_{3-}$ $\mathrm{PW}_{12} \mathrm{O}_{40}>\alpha-\mathrm{K}_{6} \mathrm{P}_{2} \mathrm{~W}_{18} \mathrm{O}_{62} \cdot 14 \mathrm{H}_{2} \mathrm{O}>\alpha-\left(\mathrm{NH}_{4}\right)_{6} \mathrm{P}_{2} \mathrm{~W}_{18} \mathrm{O}_{62}>\mathrm{K}_{8}\left[\gamma-\mathrm{SiW}_{10} \mathrm{O}_{36}\right]>\mathrm{H}_{4} \mathrm{GeW}_{12} \mathrm{O}_{40} \approx \mathrm{K}_{4} \mathrm{GeW}_{12} \mathrm{O}_{40}$ $\approx \mathrm{H}_{4} \mathrm{SiW}_{12} \mathrm{O}_{40}$. From the results, the lacunary-Keggin POMs, $\mathrm{Na}_{10}\left[\alpha-\mathrm{GeW}_{9} \mathrm{O}_{34}\right], \mathrm{Na}_{8} \mathrm{H}\left[\alpha-\mathrm{PW}_{9} \mathrm{O}_{34}\right]$, $\mathrm{Na}_{10}\left[\alpha-\mathrm{SiW}_{9} \mathrm{O}_{34}\right]$ and $\mathrm{Na}_{10} \mathrm{H}_{2} \mathrm{~W}_{12} \mathrm{O}_{42}$ are higher affinity to the substrate of OPD than TMB. There are tiny absorbance peaks (OD values of $0.0100,0.0070,0.0017$ and 0.0317 ) can be found in the above four POMs with TMB as substrates. The result indicated that peroxidase-like activities of POMs may substrate-dependence. However, no matter which the substrate was, the sandwich-type $\mathrm{K}_{10} \mathrm{P}_{2} \mathrm{~W}_{18} \mathrm{Fe}_{4}\left(\mathrm{H}_{2} \mathrm{O}\right)_{2} \mathrm{O}_{68}$ showed the highest peroxidase activity. Under the same substrate, it was found that the hybrid atoms had effect on the peroxidase activities of the POMs and the order was $\mathrm{P}>\mathrm{Si}>\mathrm{Ge}$. In the same hybrid atom and TMB substrate, the peroxidase activity order is Keggin structure $>$ Wells-Dawson $>$ lacunary-Keggin. The reactions were also carried out in the absence of the POMs at their various suitable $\mathrm{pH}$ values, respectively. No significant unspecific oxidation reactions were observed [Supplementary Figs S3, S4] even after half an hour. Additional control experiments using POMs in absence of $\mathrm{H}_{2} \mathrm{O}_{2}$ showed that no oxidative reaction occurs. Hence, these POMs had only the peroxidase-like activities defeating many mimic enzyme peroxidases which also display oxidase-like activities. The enzymatic properties of these POMs are specificity and rarely reported in the literatures ${ }^{11}$.

The polyoxomolybdates $\left(\mathrm{H}_{3} \mathrm{PMo}_{12} \mathrm{O}_{40}, \mathrm{H}_{4} \mathrm{SiMo}_{12} \mathrm{O}_{40}, \mathrm{Eu}_{3} \mathrm{PMo}_{12} \mathrm{O}_{40}, \alpha-1,2,3,-\mathrm{K}_{6} \mathrm{H}\left[\mathrm{SiW}_{9} \mathrm{~V}_{3} \mathrm{O}_{34}\right]\right.$, $\mathrm{H}_{5} \mathrm{PMo}_{10} \mathrm{~V}_{2} \mathrm{O}_{40}$ and $\mathrm{H}_{6} \mathrm{P}_{2} \mathrm{Mo}_{18} \mathrm{O}_{62}$ ) are capable of catalyzing oxidase reactions with both substrates TMB and OPD in the absence of $\mathrm{H}_{2} \mathrm{O}_{2}$ to produce a blue color (maximum absorbance $650 \mathrm{~nm}$ ) and orange color (maximum absorbance $450 \mathrm{~nm}$ ) reaction, respectively, as shown in Fig. 1b. Furthermore, the oxidase-like activities of these POMs are similar in the present of different substrates. For TMB as organic substrate, the absorption values indicated that the order of oxidase-like activities from high to low was $\mathrm{H}_{6} \mathrm{P}_{2} \mathrm{Mo}_{18} \mathrm{O}_{62}>\alpha-1,2,3-\mathrm{K}_{6} \mathrm{H}\left[\mathrm{SiW}_{9} \mathrm{~V}_{3} \mathrm{O}_{34}\right]>\mathrm{H}_{5} \mathrm{PMo}_{10} \mathrm{~V}_{2} \mathrm{O}_{40}>\mathrm{H}_{4} \mathrm{SiMo}_{12} \mathrm{O}_{40}>\mathrm{H}_{3} \mathrm{PMo}_{12} \mathrm{O}_{40}>\mathrm{Eu}_{3} \mathrm{PMo}_{12} \mathrm{O}_{40}$. For OPD as substrate, the order of oxidase-like activities from high to low was $\alpha-1,2,3-\mathrm{K}_{6} \mathrm{H}$ [Si$\left.\mathrm{W}_{9} \mathrm{~V}_{3} \mathrm{O}_{34}\right]>\mathrm{H}_{5} \mathrm{PMo}_{10} \mathrm{~V}_{2} \mathrm{O}_{40}>\mathrm{H}_{4} \mathrm{SiMo}_{12} \mathrm{O}_{40}>\mathrm{H}_{3} \mathrm{PMo}_{12} \mathrm{O}_{40}>\mathrm{Eu}_{3} \mathrm{PMo}_{12} \mathrm{O}_{40}$. In the OPD substrate, the color of $\mathrm{H}_{6} \mathrm{P}_{2} \mathrm{Mo}_{18} \mathrm{O}_{62}$ catalytic reaction solution became dark blue with a maximum absorption peak at $710 \mathrm{~nm}$. The maximum absorption peak matched with the hybrid blue, the reduction product of $\mathrm{H}_{6} \mathrm{P}_{2} \mathrm{Mo}_{18} \mathrm{O}_{62}$, which covered the absorption peak of the oxide product of OPD. Therefore, only TMB was chosen as the substrate for $\mathrm{H}_{6} \mathrm{P}_{2} \mathrm{Mo}_{18} \mathrm{O}_{62}$. Finally, $\mathrm{K}_{4} \mathrm{GeW}_{12} \mathrm{O}_{40}$ did not show the peroxidase and oxidase activities.

Effect of $\mathrm{pH}$. The effect of $\mathrm{pH}$ on the catalytic activities of different types of POMs was measured by varying the $\mathrm{pH}$ and keeping the OPD and $\mathrm{H}_{2} \mathrm{O}_{2}$ concentration constant. The absorbance value of DAB with $\mathrm{H}_{3} \mathrm{PW}_{12} \mathrm{O}_{40}$ and $\mathrm{Na}_{10} \mathrm{H}_{2} \mathrm{~W}_{12} \mathrm{O}_{42}$ reached a maximum at the $\mathrm{pH} 2.5$, as shown in Fig. 2a,b. After exceeding this point, the absorbance decreased gradually as increasing $\mathrm{pH}$ values. Therefore, $\mathrm{pH} 2.5$ was selected as the optimal $\mathrm{pH}$ value for $\mathrm{H}_{3} \mathrm{PW}_{12} \mathrm{O}_{40}$ and $\mathrm{Na}_{10} \mathrm{H}_{2} \mathrm{~W}_{12} \mathrm{O}_{42}$. Similarly, $\mathrm{pH} 5$ was selected as the optimal $\mathrm{pH}$ value for $\mathrm{K}_{10} \mathrm{P}_{2} \mathrm{~W}_{18} \mathrm{Fe}_{4}\left(\mathrm{H}_{2} \mathrm{O}\right)_{2} \mathrm{O}_{68}$, as shown in Fig. 2c. Interestingly, the catalytic activity of the $\mathrm{Na}_{10}\left[\alpha-\mathrm{GeW}_{9} \mathrm{O}_{34}\right]$, $\mathrm{Na}_{8} \mathrm{H}\left[\alpha-\mathrm{PW}_{9} \mathrm{O}_{34}\right]$ and $\mathrm{Na}_{10}\left[\alpha-\mathrm{SiW}_{9} \mathrm{O}_{34}\right]$ shows a $\mathrm{pH}$ optimum at alkaline conditions $(\sim 10)$. At this $\mathrm{pH}$ and in the absence of $\mathrm{Na}_{10}\left[\alpha-\mathrm{GeW}_{9} \mathrm{O}_{34}\right], \mathrm{Na}_{8} \mathrm{H}\left[\alpha-\mathrm{PW}_{9} \mathrm{O}_{34}\right]$ and $\mathrm{Na}_{10}\left[\alpha-\mathrm{SiW}_{9} \mathrm{O}_{34}\right]$ the unspecific reaction between OPD $(576 \mu \mathrm{M})$ and $\mathrm{H}_{2} \mathrm{O}_{2}(200 \mathrm{mM})$ was not observed. As mentioned, most of the known peroxidase-like POMs based artificial enzymes show their high activities at acid condition. Some POMs hybrids, such as inorganic-organic hybrids and FA functional particles exhibit oxidation catalyst at $\mathrm{pH}$ about $7.0^{22,25}$. However, $\mathrm{Na}_{10}\left[\alpha-\mathrm{GeW}_{9} \mathrm{O}_{34}\right]$, $\mathrm{Na}_{8} \mathrm{H}\left[\alpha-\mathrm{PW}_{9} \mathrm{O}_{34}\right]$ and $\mathrm{Na}_{10}\left[\alpha-\mathrm{SiW}_{9} \mathrm{O}_{34}\right]$ are highly active even at $\mathrm{pH}$ above 10 , as shown in Fig. $2 \mathrm{~d}-\mathrm{f}$. Based on the catalytic properties of these trivacant Keggin heterotungstates, we build a CdTe quantum dots (QDs)-based fluorometric method for sensitive detection of hydrogen peroxide ${ }^{35}$. The effect of $\mathrm{pH}$ on the catalytic activities of $\mathrm{H}_{3} \mathrm{PW}_{12} \mathrm{O}_{40}$ and $\mathrm{K}_{10} \mathrm{P}_{2} \mathrm{~W}_{18} \mathrm{Fe}_{4}\left(\mathrm{H}_{2} \mathrm{O}\right)_{2} \mathrm{O}_{68}$ with $\mathrm{TMB}$ as substrate were also investigated, as shown in Supplementary Fig. S5. The optimal $\mathrm{pH}$ for $\mathrm{H}_{3} \mathrm{PW}_{12} \mathrm{O}_{40}$ and $\mathrm{K}_{10} \mathrm{P}_{2} \mathrm{~W}_{18} \mathrm{Fe}_{4}\left(\mathrm{H}_{2} \mathrm{O}\right)_{2} \mathrm{O}_{68}$ were 2.5 and 4, respectively.

Analogously, the reaction $\mathrm{pH}$-dependent response curves on oxidase mimics $\mathrm{H}_{3} \mathrm{PMo}_{12} \mathrm{O}_{40}, \mathrm{H}_{4} \mathrm{SiMo}_{12} \mathrm{O}_{40}$, $\mathrm{Eu}_{3} \mathrm{PMo}_{12} \mathrm{O}_{40}, \mathrm{H}_{5} \mathrm{PMo}_{10} \mathrm{~V}_{2} \mathrm{O}_{40}$ and $\alpha-1,2,3-\mathrm{K}_{6} \mathrm{H}-\left[\mathrm{SiW}_{9} \mathrm{~V}_{3} \mathrm{O}_{34}\right]$ with OPD as substrates and $\mathrm{H}_{6} \mathrm{P}_{2} \mathrm{Mo}_{18} \mathrm{O}_{62}$ with TMB as substrate were shown in Fig. 3. When the $\mathrm{pH}$ value increased from 2.0 to 7 , the absorbance reached the maximums at $\mathrm{pH} 4,5,3,2.5,4$ and 5 for $\mathrm{H}_{3} \mathrm{PMo}_{12} \mathrm{O}_{40}, \mathrm{H}_{4} \mathrm{SiMo}_{12} \mathrm{O}_{40}, \mathrm{Eu}_{3} \mathrm{PMo}_{12} \mathrm{O}_{40}, \mathrm{H}_{5} \mathrm{PMo}_{10} \mathrm{~V}_{2} \mathrm{O}_{40}$, $\alpha-1,2,3-\mathrm{K}_{6} \mathrm{H}\left[\mathrm{SiW}_{9} \mathrm{~V}_{3} \mathrm{O}_{34}\right]$ and $\mathrm{H}_{6} \mathrm{P}_{2} \mathrm{Mo}_{18} \mathrm{O}_{62}$, respectively. The effect of $\mathrm{pH}$ on the catalytic activities of $\mathrm{H}_{3} \mathrm{PMo}_{12} \mathrm{O}_{40}, \mathrm{H}_{4} \mathrm{SiMo}_{12} \mathrm{O}_{40}, \mathrm{Eu}_{3} \mathrm{PMo}_{12} \mathrm{O}_{40}, \mathrm{H}_{5} \mathrm{PMo}_{10} \mathrm{~V}_{2} \mathrm{O}_{40}$ and $\alpha-1,2,3-\mathrm{K}_{6} \mathrm{H}\left[\mathrm{SiW}_{9} \mathrm{~V}_{3} \mathrm{O}_{34}\right]$ with TMB as substrate were also investigated, as shown in Supplementary Fig. S6. When TMB as substrates, $\mathrm{H}_{3} \mathrm{PMo}_{12} \mathrm{O}_{40}, \mathrm{H}_{4} \mathrm{SiMo}_{12} \mathrm{O}_{40}$, $\mathrm{Eu}_{3} \mathrm{PMo}_{12} \mathrm{O}_{40}, \mathrm{H}_{5} \mathrm{PMo}_{10} \mathrm{~V}_{2} \mathrm{O}_{40}$ and $\alpha-1,2,3-\mathrm{K}_{6} \mathrm{H}\left[\mathrm{SiW}_{9} \mathrm{~V}_{3} \mathrm{O}_{34}\right]$ exhibited their strongest activities when the $\mathrm{pH}$ was $4,5,4,2.5$ and 4 , respectively. 

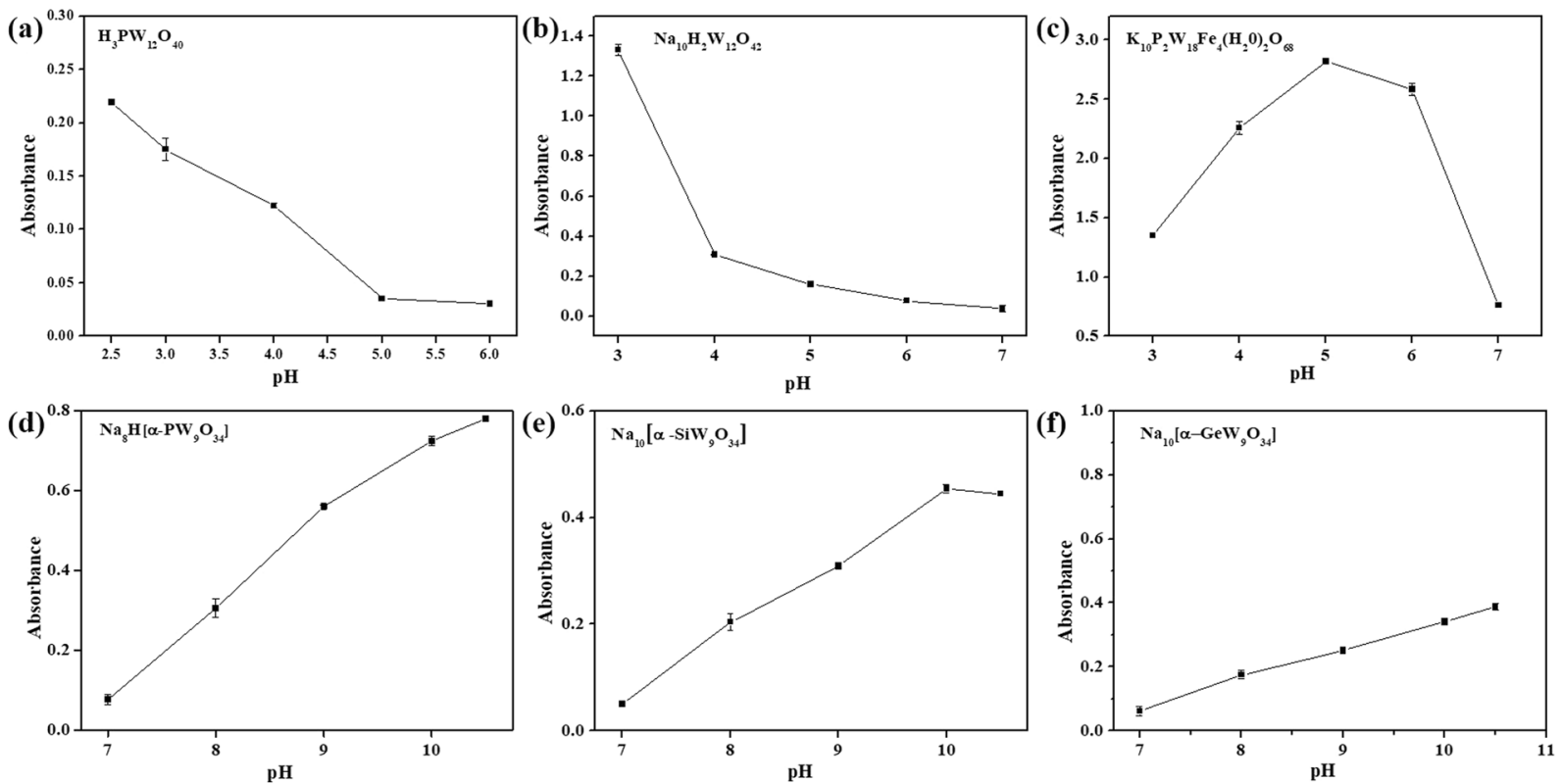

Figure 2. Effects of $\mathrm{pH}$ on peroxidase-like enzymes with $\mathrm{OPD}$ as a substrate, respectively. (a) $\mathrm{H}_{3} \mathrm{PW}_{12} \mathrm{O}_{40} ;$ (b) $\mathrm{Na}_{10} \mathrm{H}_{2} \mathrm{~W}_{12} \mathrm{O}_{42} ;$ (c) $\mathrm{K}_{10} \mathrm{P}_{2} \mathrm{~W}_{18} \mathrm{Fe}_{4}\left(\mathrm{H}_{2} \mathrm{O}\right)_{2} \mathrm{O}_{68} ;$ (d) $\mathrm{Na}_{8} \mathrm{H}\left[\alpha-\mathrm{PW}_{9} \mathrm{O}_{34}\right] ;$ (e) $\mathrm{Na}_{10}\left[\alpha-\mathrm{SiW}_{9} \mathrm{O}_{34}\right] ;$ (f) $\mathrm{Na}_{10}\left[\alpha-\mathrm{GeW}_{9} \mathrm{O}_{34}\right]$; Conditions: $200 \mu \mathrm{M}$ POMs, $200 \mathrm{mM} \mathrm{H}_{2} \mathrm{O}_{2}, 0.2 \mathrm{mM} \mathrm{Na}_{2} \mathrm{HPO}_{4}$-citrate buffer for $\mathrm{H}_{3} \mathrm{PW}_{12} \mathrm{O}_{40}, \mathrm{Na}_{10} \mathrm{H}_{2} \mathrm{~W}_{12} \mathrm{O}_{42}$ and $\mathrm{K}_{10} \mathrm{P}_{2} \mathrm{~W}_{18} \mathrm{Fe}_{4}\left(\mathrm{H}_{2} \mathrm{O}\right)_{2} \mathrm{O}_{68} ; 0.1 \mathrm{mM}$ Tris- $\mathrm{HCl}$ for $\mathrm{Na}_{8} \mathrm{H}\left[\alpha-\mathrm{PW}_{9} \mathrm{O}_{34}\right], \mathrm{Na}_{10}\left[\alpha-\mathrm{SiW}_{9} \mathrm{O}_{34}\right]$ and $\mathrm{Na}_{10}\left[\alpha-\mathrm{GeW}_{9} \mathrm{O}_{34}\right]$ at room temperature for 10 minutes. The error bars represent the standard deviation of three measurements.
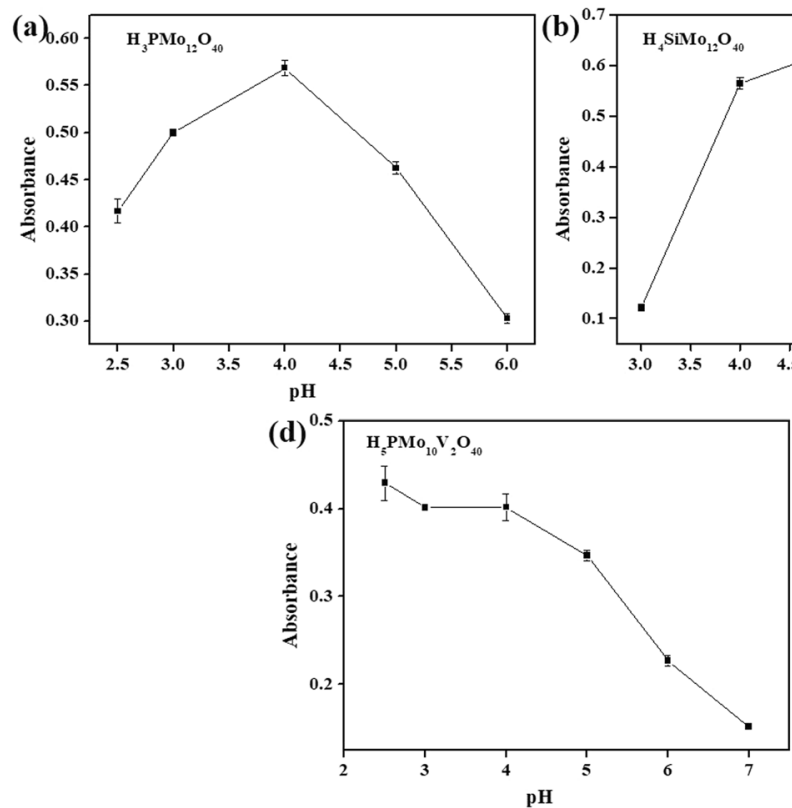
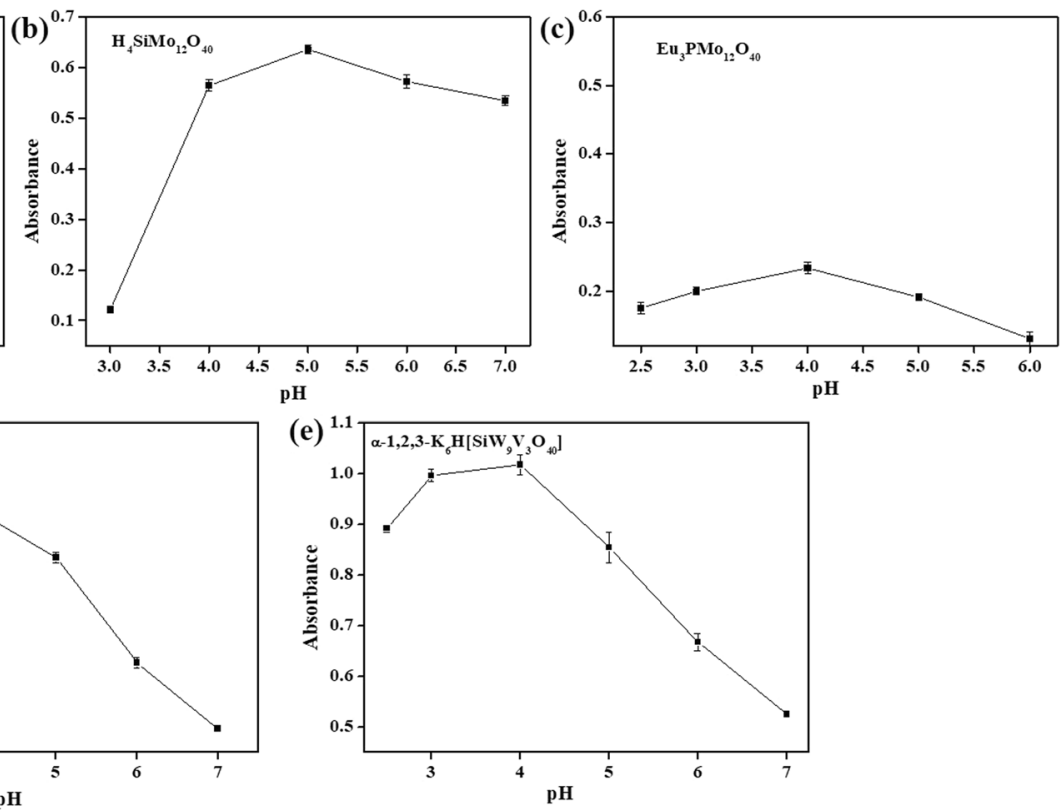

Figure 3. Effects of $\mathrm{pH}$ on oxidase-like enzymes with OPD as a substrate. (a) $\mathrm{H}_{3} \mathrm{PMo}_{12} \mathrm{O}_{40} ;(\mathbf{b}) \mathrm{H}_{4} \mathrm{SiMo}_{12} \mathrm{O}_{40}$; (c) $\mathrm{Eu}_{3} \mathrm{PMo}_{12} \mathrm{O}_{40}$; (d) $\mathrm{H}_{5} \mathrm{PMo}_{10} \mathrm{~V}_{2} \mathrm{O}_{40} ;$ (e) $\alpha-1,2,3-\mathrm{K}_{6} \mathrm{H}\left[\mathrm{SiW}_{9} \mathrm{~V}_{3} \mathrm{O}_{34}\right]$; (f) $\mathrm{H}_{6} \mathrm{P}_{2} \mathrm{Mo}_{18} \mathrm{O}_{62}$ with TMB as substrates. Conditions: $200 \mu \mathrm{M}$ POMs, $200 \mathrm{mM} \mathrm{H}_{2} \mathrm{O}_{2}, 0.2 \mathrm{mM} \mathrm{Na}_{2} \mathrm{HPO}_{4}$-citrate buffer at room temperature for 10 minutes. The error bars represent the standard deviation of three measurements.

Effect of concentration of POMs. The OPD oxidation rate catalyzed by the peroxidase-like POMs was dependent on the concentration of these POMs with the other parameters were kept constant, as shown in Fig. 4. In a typical experiment, the POMs oxidation activity was determined by monitoring of the absorbance at $450 \mathrm{~nm}$ (which increases because of $\mathrm{DAB}$, the oxidation product of $\mathrm{OPD}$, formation) for $10 \mathrm{~min}$ at $25^{\circ} \mathrm{C}$ in different buffer for varying concentrations of POMs with respect to OPD (576 $\mu \mathrm{M})$ and $\mathrm{H}_{2} \mathrm{O}_{2}(200 \mathrm{mM})$. It can be found that the greater the amount of catalyst, the higher the yield of DAB. The increasing of the DAB yield becomes gentle when the amount of $\mathrm{H}_{3} \mathrm{PW}_{12} \mathrm{O}_{40}, \mathrm{Na}_{10} \mathrm{H}_{2} \mathrm{~W}_{12} \mathrm{O}_{42}, \mathrm{Na}_{10}\left[\alpha-\mathrm{GeW}_{9} \mathrm{O}_{34}\right], \mathrm{Na}_{8} \mathrm{H}\left[\alpha-\mathrm{PW}_{9} \mathrm{O}_{34}\right]$, 

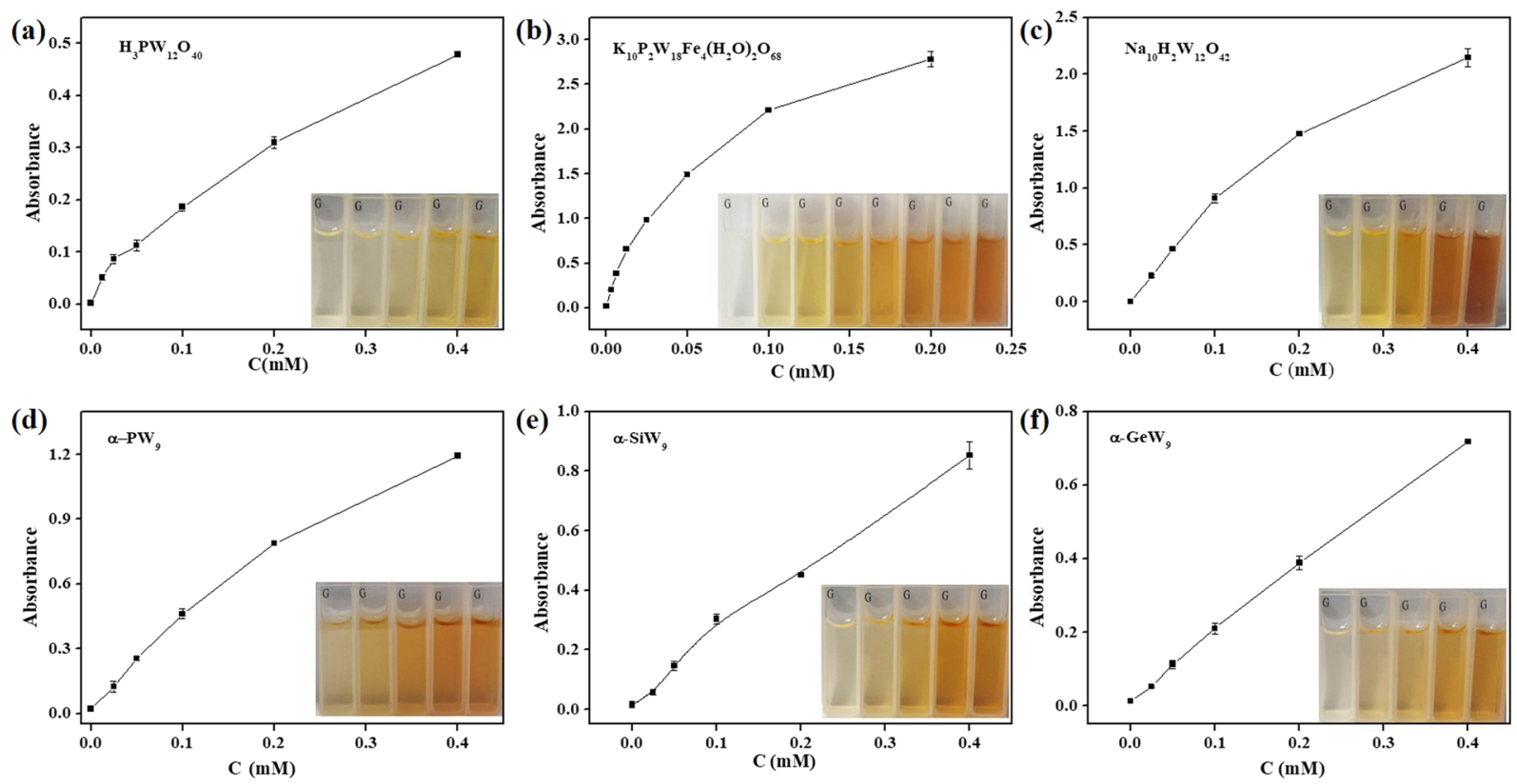

Figure 4. Effects of concentrations of peroxidase-like enzymes with OPD as a substrate. $(\mathbf{a}) \mathrm{H}_{3} \mathrm{PW}_{12} \mathrm{O}_{40}$; (b) $\mathrm{Na}_{10} \mathrm{H}_{2} \mathrm{~W}_{12} \mathrm{O}_{42} ;$; (c) $\mathrm{K}_{10} \mathrm{P}_{2} \mathrm{~W}_{18} \mathrm{Fe}_{4}\left(\mathrm{H}_{2} \mathrm{O}\right)_{2} \mathrm{O}_{68} ;$; d $\mathrm{Na}_{8} \mathrm{H}\left[\alpha-\mathrm{PW}_{9} \mathrm{O}_{34}\right]$; (e) $\mathrm{Na}_{10}\left[\alpha-\mathrm{SiW}_{9} \mathrm{O}_{34}\right] ;\left(\right.$ f) $\mathrm{Na}_{10}[\alpha-$ $\mathrm{GeW}_{9} \mathrm{O}_{34}$; ; Conditions: $200 \mathrm{mM} \mathrm{H}_{2} \mathrm{O}_{2}, 0.2 \mathrm{mM} \mathrm{Na}_{2} \mathrm{HPO}_{4}$-citrate buffer for $\mathrm{H}_{3} \mathrm{PW}_{12} \mathrm{O}_{40}, \mathrm{Na}_{10} \mathrm{H}_{2} \mathrm{~W}_{12} \mathrm{O}_{42}$ and $\mathrm{K}_{10} \mathrm{P}_{2} \mathrm{~W}_{18} \mathrm{Fe}_{4}\left(\mathrm{H}_{2} \mathrm{O}\right)_{2} \mathrm{O}_{68} ; 0.1 \mathrm{mM}$ Tris- $\mathrm{HCl}$ for $\mathrm{Na}_{8} \mathrm{H}\left[\alpha-\mathrm{PW}_{9} \mathrm{O}_{34}\right], \mathrm{Na}_{10}\left[\alpha-\mathrm{SiW}_{9} \mathrm{O}_{34}\right]$ and $\mathrm{Na}_{10}\left[\alpha-\mathrm{GeW}_{9} \mathrm{O}_{34}\right]$ at room temperature for 10 minutes. The error bars represent the standard deviation of three measurements.

$\mathrm{Na}_{10}\left[\alpha-\mathrm{SiW}_{9} \mathrm{O}_{34}\right]$ and $\mathrm{K}_{10} \mathrm{P}_{2} \mathrm{~W}_{18} \mathrm{Fe}_{4}\left(\mathrm{H}_{2} \mathrm{O}\right)_{2} \mathrm{O}_{68}$ exceeds $0.4,0.4,0.4,0.4,0.4$ and $0.1 \mathrm{mM}$, respectively. Furthermore, $\mathrm{Na}_{10}\left[\alpha-\mathrm{GeW}_{9} \mathrm{O}_{34}\right], \mathrm{Na}_{8} \mathrm{H}\left[\alpha-\mathrm{PW}_{9} \mathrm{O}_{34}\right]$ and $\mathrm{Na}_{10}\left[\alpha-\mathrm{SiW}_{9} \mathrm{O}_{34}\right]$ were insoluble when the concentrations were beyond $0.4 \mathrm{mM}$. Therefore, $0.4 \mathrm{mM}$ was chosen as the optimum concentrations of $\mathrm{H}_{3} \mathrm{PW}_{12} \mathrm{O}_{40}, \mathrm{Na}_{10} \mathrm{H}_{2} \mathrm{~W}_{12} \mathrm{O}_{42}$, $\mathrm{Na}_{10}\left[\alpha-\mathrm{GeW}_{9} \mathrm{O}_{34}\right], \mathrm{Na}_{8} \mathrm{H}\left[\alpha-\mathrm{PW}_{9} \mathrm{O}_{34}\right]$ and $\mathrm{Na}_{10}\left[\alpha-\mathrm{SiW}_{9} \mathrm{O}_{34}\right]$ for the kinetics experiments. While, $0.1 \mathrm{mM}$ was chosen for $\mathrm{K}_{10} \mathrm{P}_{2} \mathrm{~W}_{18} \mathrm{Fe}_{4}\left(\mathrm{H}_{2} \mathrm{O}\right)_{2} \mathrm{O}_{68}$. The effect of the amounts of $\mathrm{H}_{3} \mathrm{PW}_{12} \mathrm{O}_{40}$ and $\mathrm{K}_{10} \mathrm{P}_{2} \mathrm{~W}_{18} \mathrm{Fe}_{4}\left(\mathrm{H}_{2} \mathrm{O}\right)_{2} \mathrm{O}_{68}$ on peroxidase-like activities with TMB as substrates were also investigated, as shown in Supplementary Fig. S7. $0.4 \mathrm{mM}$ and $0.1 \mathrm{mM}$ were chosen for $\mathrm{H}_{3} \mathrm{PW}_{12} \mathrm{O}_{40}$ and $\mathrm{K}_{10} \mathrm{P}_{2} \mathrm{~W}_{18} \mathrm{Fe}_{4}\left(\mathrm{H}_{2} \mathrm{O}\right)_{2} \mathrm{O}_{68}$ as the optimum concentrations, respectively.

As shown in Fig. 5, the effect of the amounts of POMs with oxidase-like activities on the yield of DAB was also investigated. The procedures were similar with above except $\mathrm{H}_{2} \mathrm{O}_{2}$. DAB is obtained without $\mathrm{H}_{2} \mathrm{O}_{2}$, while the absorbance of DAB increases along with the increase in the amount of $\mathrm{H}_{3} \mathrm{PMo}_{12} \mathrm{O}_{40}, \mathrm{H}_{4} \mathrm{SiMo}_{12} \mathrm{O}_{40}$ and $\mathrm{Eu}_{3} \mathrm{PMo}_{12} \mathrm{O}_{40}$ and reached the maximum at $0.4 \mathrm{mM}$ POMs. The maximum concentrations of $\mathrm{H}_{5} \mathrm{PMo}_{10} \mathrm{~V}_{2}$ and $\alpha-1,2,3-\mathrm{K}_{6} \mathrm{H}\left[\mathrm{SiW}_{9} \mathrm{~V}_{3} \mathrm{O}_{34}\right]$ were $0.2 \mathrm{mM}$. The maximum concentration of $\mathrm{H}_{6} \mathrm{P}_{2} \mathrm{Mo}_{18} \mathrm{O}_{62}$ with TMB as substrates was $50 \mu \mathrm{M}$. As shown in Fig. S8, when TMB were substrates, we found that the optimum concentration was $0.1 \mathrm{mM}$ for $\mathrm{H}_{3} \mathrm{PMo}_{12} \mathrm{O}_{40}, \mathrm{H}_{5} \mathrm{PMo}_{10} \mathrm{~V}_{2}$ and $\alpha-1,2,3-\mathrm{K}_{6} \mathrm{H}\left[\mathrm{SiW}_{9} \mathrm{~V}_{3} \mathrm{O}_{34}\right] . \mathrm{H}_{4} \mathrm{SiMo}_{12} \mathrm{O}_{40}$ and $\mathrm{Eu}_{3} \mathrm{PMo}_{12} \mathrm{O}_{40}$ reached their maximum absorption values when the concentrations were $0.2 \mathrm{mM}$ and $0.4 \mathrm{mM}$, respectively.

Effect of reaction time. The variation of the DAB yield with increasing reaction time is shown in Fig. 6. It can be observed that absorption value of $\mathrm{DAB}$ reaches a maximum during a reaction time of less than $10 \mathrm{~min}$ utes and 1 minute for peroxidase and oxidase when $200 \mathrm{mM} \mathrm{H}_{2} \mathrm{O}_{2}$ and $576 \mu \mathrm{M}$ OPD were used, respectively. After that, along with the increasing of reaction time, the yield of $\mathrm{DAB}$ remains nearly constant. This indicates that the optimized reaction time were 10 minutes for $\mathrm{H}_{3} \mathrm{PW}_{12} \mathrm{O}_{40}, \mathrm{Na}_{10}\left[\alpha-\mathrm{GeW}_{9} \mathrm{O}_{34}\right], \mathrm{Na}_{8} \mathrm{H}\left[\alpha-\mathrm{PW}_{9} \mathrm{O}_{34}\right]$ and $\mathrm{Na}_{10}\left[\alpha-\mathrm{SiW}_{9} \mathrm{O}_{34}\right], 5$ minutes for $\mathrm{K}_{10} \mathrm{P}_{2} \mathrm{~W}_{18} \mathrm{Fe}_{4}\left(\mathrm{H}_{2} \mathrm{O}\right)_{2} \mathrm{O}_{68}$ and 2 minutes for $\mathrm{Na}_{10} \mathrm{H}_{2} \mathrm{~W}_{12} \mathrm{O}_{42}$, as shown in Fig. $6 \mathrm{a}$. The reaction time for oxidase were less than $60 \mathrm{~s}$ for $\mathrm{H}_{3} \mathrm{PMo}_{12} \mathrm{O}_{40}, \mathrm{H}_{4} \mathrm{SiMo}_{12} \mathrm{O}_{40}, \mathrm{Eu}_{3} \mathrm{PMo}_{12} \mathrm{O}_{40}, \mathrm{H}_{5} \mathrm{PMo}_{10} \mathrm{~V}_{2} \mathrm{O}_{40}$, $\alpha-1,2,3-\mathrm{K}_{6} \mathrm{H}\left[\mathrm{SiW}_{9} \mathrm{~V}_{3} \mathrm{O}_{34}\right]$ and $\mathrm{H}_{6} \mathrm{P}_{2} \mathrm{Mo}_{18} \mathrm{O}_{62}$.

Kinetic parameters. The mechanism of peroxidase-like catalytic activities of $\mathrm{K}_{10} \mathrm{P}_{2} \mathrm{~W}_{18} \mathrm{Fe}_{4}\left(\mathrm{H}_{2} \mathrm{O}\right)_{2} \mathrm{O}_{68}$, $\mathrm{H}_{3} \mathrm{PW}_{12} \mathrm{O}_{40}, \mathrm{H}_{4} \mathrm{SiW}_{12} \mathrm{O}_{40}, \mathrm{Na}_{10}\left[\alpha-\mathrm{GeW}_{9} \mathrm{O}_{34}\right], \mathrm{Na}_{8} \mathrm{H}\left[\alpha-\mathrm{PW}_{9} \mathrm{O}_{34}\right], \mathrm{Na}_{10}\left[\alpha-\mathrm{SiW}_{9} \mathrm{O}_{34}\right]$ and $\mathrm{Na}_{10} \mathrm{H}_{2} \mathrm{~W}_{12} \mathrm{O}_{42}$ was further investigated using steady-state kinetics. It has been observed that OPD oxidation catalysis mediated by these POMs is dependent on the substrate concentration. In order to study activities of POMs, several experiments were performed whereby the concentration of either OPD or $\mathrm{H}_{2} \mathrm{O}_{2}$ was varied while keeping the other concentration constant. The concentration of the POMs was kept constant in all these experiments. The oxidation reaction catalyzed by $\mathrm{K}_{10} \mathrm{P}_{2} \mathrm{~W}_{18} \mathrm{Fe}_{4}\left(\mathrm{H}_{2} \mathrm{O}\right)_{2} \mathrm{O}_{68}, \mathrm{H}_{3} \mathrm{PW}_{12} \mathrm{O}_{40}, \mathrm{H}_{4} \mathrm{SiW}_{12} \mathrm{O}_{40}, \mathrm{Na}_{10}\left[\alpha-\mathrm{GeW}_{9} \mathrm{O}_{34}\right], \mathrm{Na}{ }_{8} \mathrm{H}\left[\alpha-\mathrm{PW}_{9} \mathrm{O}_{34}\right], \mathrm{Na}_{10}\left[\alpha-\mathrm{SiW}_{9} \mathrm{O}_{34}\right]$ and $\mathrm{Na}_{10} \mathrm{H}_{2} \mathrm{~W}_{12} \mathrm{O}_{42}$ follows a Michaelis-Menten behavior. The $K_{m}$ and $V_{\max }$ of $\mathrm{K}_{10} \mathrm{P}_{2} \mathrm{~W}_{18} \mathrm{Fe}_{4}\left(\mathrm{H}_{2} \mathrm{O}\right)_{2} \mathrm{O}_{68}$ and $\mathrm{H}_{3} \mathrm{PW}_{12} \mathrm{O}_{40}$ were obtained using a Line weaver-Burk plot with OPD as substrates, as shown in Fig. 7. The $K_{m}$ and $V_{\max }$ of $\mathrm{K}_{10} \mathrm{P}_{2} \mathrm{~W}_{18} \mathrm{Fe}_{4}\left(\mathrm{H}_{2} \mathrm{O}\right)_{2} \mathrm{O}_{68}$ with $\mathrm{H}_{2} \mathrm{O}_{2}$ as substrates were $0.113 \mathrm{mM}$ and $1.13 \times 10^{-9} \mathrm{M} \cdot \mathrm{S}^{-1}$ in OPD system, as shown in Fig. 7a. The $K_{m}$ and $V_{\text {max }}$ of $\mathrm{K}_{10} \mathrm{P}_{2} \mathrm{~W}_{18} \mathrm{Fe}_{4}\left(\mathrm{H}_{2} \mathrm{O}\right)_{2} \mathrm{O}_{68}$ with OPD as substrates were $0.109 \mathrm{mM}$ and $4.11 \times 10^{-8} \mathrm{M} \cdot \mathrm{S}^{-1}$, 

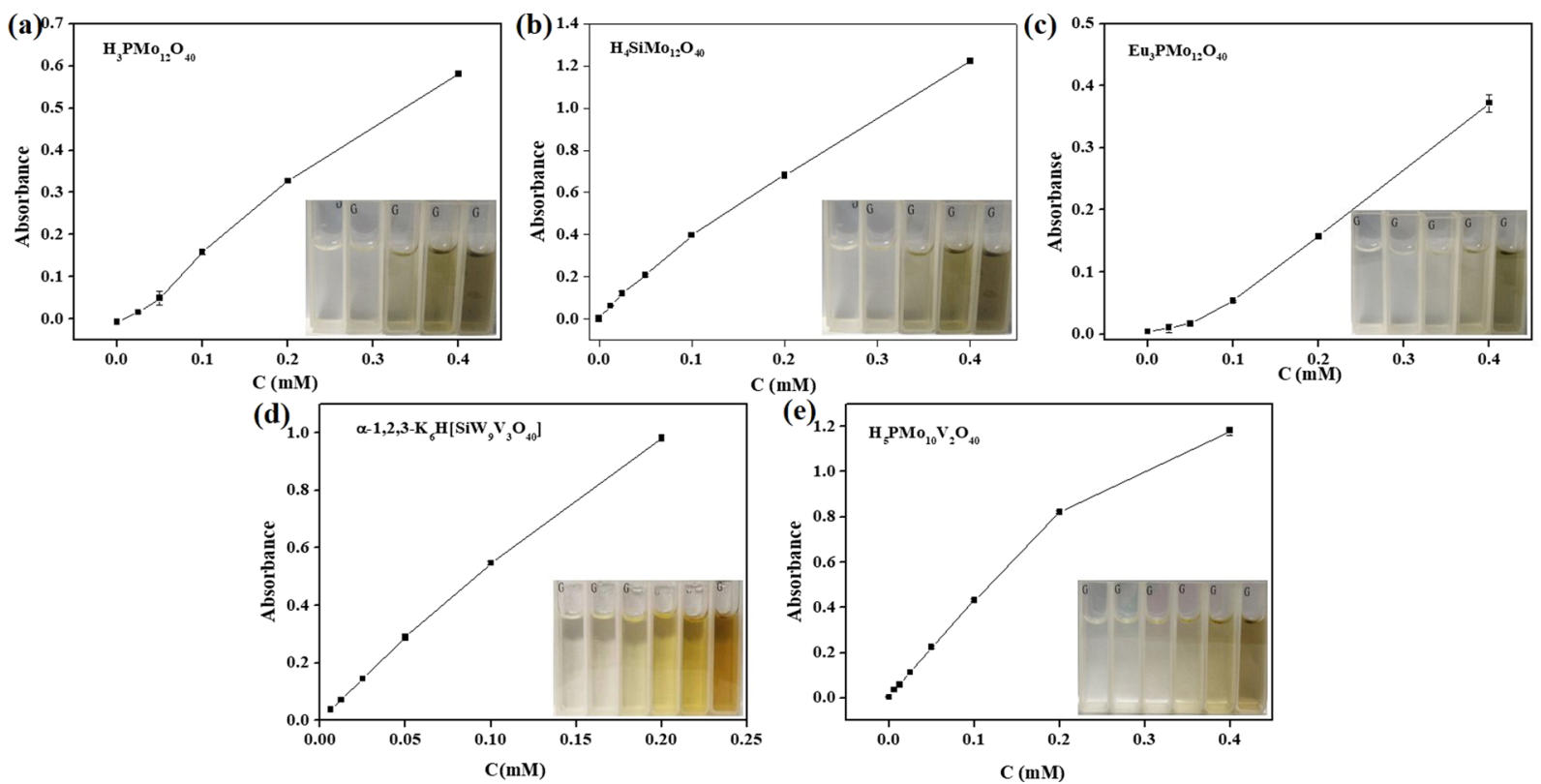

Figure 5. Effects of concentrations of oxidase-like enzymes with OPD as a substrate. (a) $\mathrm{H}_{3} \mathrm{PMo}_{12} \mathrm{O}_{40} ;$; (b) $\mathrm{H}_{4} \mathrm{SiMo}_{12} \mathrm{O}_{40} ;(\mathbf{c}) \mathrm{Eu}_{3} \mathrm{PMo}_{12} \mathrm{O}_{40} ;(\mathbf{d}) \mathrm{H}_{5} \mathrm{PMo}_{10} \mathrm{~V}_{2} \mathrm{O}_{40} ;(\mathbf{e}) \alpha-1,2,3-\mathrm{K}_{6} \mathrm{H}\left[\mathrm{SiW}_{9} \mathrm{~V}_{3} \mathrm{O}_{34}\right] ;(\mathbf{f}) \mathrm{H}_{6} \mathrm{P}_{2} \mathrm{Mo}_{18} \mathrm{O}_{62}$ with TMB as substrates. Conditions: $0.2 \mathrm{mM} \mathrm{Na}_{2} \mathrm{HPO}_{4}$-citrate buffer at room temperature for 10 minutes. The error bars represent the standard deviation of three measurements.
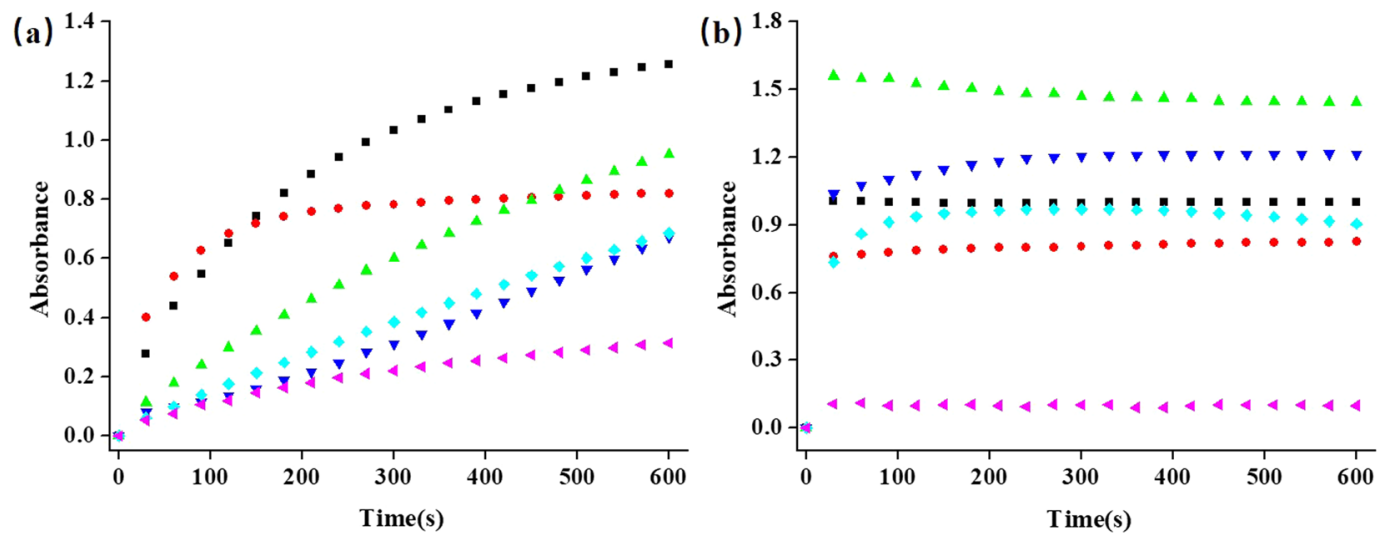

Figure 6. The reaction time of different-type POMs. (a) peroxidase (black: $\mathrm{K}_{10} \mathrm{P}_{2} \mathrm{~W}_{18} \mathrm{Fe}_{4}\left(\mathrm{H}_{2} \mathrm{O}\right)_{2} \mathrm{O}_{68}$; red: $\mathrm{Na}_{10} \mathrm{H}_{2} \mathrm{~W}_{12} \mathrm{O}_{42}$; green: $\mathrm{Na}_{8} \mathrm{H}\left[\alpha-\mathrm{PW}_{9} \mathrm{O}_{34}\right.$; light blue: [ $\left.\alpha-\mathrm{SiW}_{9} \mathrm{O}_{34}\right]$; dark blue: $\mathrm{Na}_{10}\left[\alpha-\mathrm{GeW}_{9} \mathrm{O}_{34}\right]$; pink: $\mathrm{H}_{3} \mathrm{PW}_{12} \mathrm{O}_{40}$ ); (b) oxidase (green: $\mathrm{H}_{6} \mathrm{P}_{2} \mathrm{Mo}_{18} \mathrm{O}_{62}$; dark blue: $\alpha-1,2,3-\mathrm{K}_{6} \mathrm{H}\left[\mathrm{SiW}_{9} \mathrm{~V}_{3} \mathrm{O}_{34}\right]$; black: $\mathrm{H}_{5} \mathrm{PMo}_{10} \mathrm{~V}_{2} \mathrm{O}_{40}$; light blue: $\mathrm{H}_{4} \mathrm{SiMo}_{12} \mathrm{O}_{40}$; red: $\mathrm{H}_{3} \mathrm{PMo}_{12} \mathrm{O}_{40}$; pink: $\mathrm{Eu}_{3} \mathrm{PMo}_{12} \mathrm{O}_{40}$ ).

as shown in Fig. 7b. The $K_{\text {cat }}$ of $\mathrm{K}_{10} \mathrm{P}_{2} \mathrm{~W}_{18} \mathrm{Fe}_{4}\left(\mathrm{H}_{2} \mathrm{O}\right)_{2} \mathrm{O}_{68}$ with $\mathrm{H}_{2} \mathrm{O}_{2}$ and $\mathrm{OPD}$ are $3.22 \times 10^{-3} \mathrm{~S}^{-1}$ and $3.80 \times 10^{-3} \mathrm{~S}^{-1}$. The $K_{m}$ and $V_{\text {max }}$ of $\mathrm{H}_{3} \mathrm{PW}_{12} \mathrm{O}_{40}$ with $\mathrm{H}_{2} \mathrm{O}_{2}$ as substrates were $6.624 \mathrm{mM}$ and $3.89 \times 10^{-9} \mathrm{M} \cdot \mathrm{S}^{-1}$ in OPD system, as shown in Fig. 7c. The $K_{m}$ and $V_{\max }$ of $\mathrm{H}_{3} \mathrm{PW}_{12} \mathrm{O}_{40}$ with OPD as substrates were $0.174 \mathrm{mM}$ and $6.14 \times 10^{-9} \mathrm{M} \cdot \mathrm{S}^{-1}$, as shown in Fig. $7 \mathrm{~d}$. The $K_{\text {cat }}$ of $\mathrm{H}_{3} \mathrm{PW}_{12} \mathrm{O}_{40}$ with $\mathrm{H}_{2} \mathrm{O}_{2}$ and $\mathrm{OPD}$ are $8.22 \times 10^{-4} \mathrm{~S}^{-1}$ and $2.83 \times 10^{-6} \mathrm{~S}^{-1}$. As shown in Fig. 8, the values for $K_{m}$ OPD of $\mathrm{Na}_{8} \mathrm{H}\left[\alpha-\mathrm{PW}_{9} \mathrm{O}_{34}\right], \mathrm{Na}_{10}\left[\alpha-\mathrm{SiW}_{9} \mathrm{O}_{34}\right], \mathrm{Na}_{10}\left[\alpha-\mathrm{GeW}_{9} \mathrm{O}_{34}\right]$ and $\mathrm{Na}_{10} \mathrm{H}_{2} \mathrm{~W}_{12} \mathrm{O}_{42}$ were $1.39,0.854,0.611$ and $0.205 \mathrm{mM}$, respectively. The values for $V_{\max } \mathrm{OPD}$ of $\mathrm{Na}_{8} \mathrm{H}\left[\alpha-\mathrm{PW}_{9} \mathrm{O}_{34}\right], \mathrm{Na}_{10}\left[\alpha-\mathrm{SiW}_{9} \mathrm{O}_{34}\right]$, $\mathrm{Na}_{10}\left[\alpha-\mathrm{GeW}_{9} \mathrm{O}_{34}\right]$ and $\mathrm{Na}_{10} \mathrm{H}_{2} \mathrm{~W}_{12} \mathrm{O}_{42}$ were $2.53 \times 10^{-8}, 8.79 \times 10^{-9}, 3.65 \times 10^{-9}$ and $2.43 \times 10^{-8} \mathrm{M} \cdot \mathrm{S}^{-1}$, respectively. The $K_{\text {cat }}$ OPD of $\mathrm{Na}_{8} \mathrm{H}\left[\alpha-\mathrm{PW}_{9} \mathrm{O}_{34}\right], \mathrm{Na}_{10}\left[\alpha-\mathrm{SiW}_{9} \mathrm{O}_{34}\right], \mathrm{Na}_{10}\left[\alpha-\mathrm{GeW}_{9} \mathrm{O}_{34}\right]$ and $\mathrm{Na}_{10} \mathrm{H}_{2} \mathrm{~W}_{12} \mathrm{O}_{42}$ were $4.912 \times 10^{-4} \mathrm{~S}^{-1}, 2.02 \times 10^{-4} \mathrm{~S}^{-1}, 7.03 \times 10^{-4} \mathrm{~S}^{-1}$ and $1.46 \times 10^{-4} \mathrm{~S}^{-1}$. The values for $K_{m} \mathrm{H}_{2} \mathrm{O}_{2}$ of $\mathrm{Na}_{8} \mathrm{H}\left[\alpha-\mathrm{PW}_{9} \mathrm{O}_{34}\right]$, $\mathrm{Na}_{10}\left[\alpha-\mathrm{SiW}_{9} \mathrm{O}_{34}\right], \mathrm{Na}_{10}\left[\alpha-\mathrm{GeW}_{9} \mathrm{O}_{34}\right]$ and $\mathrm{Na}_{10} \mathrm{H}_{2} \mathrm{~W}_{12} \mathrm{O}_{42}$ were $13.81,63.55,44.05$, and $132.03 \mathrm{mM}$, respectively. The $V_{\text {max }} \mathrm{H}_{2} \mathrm{O}_{2}$ of $\mathrm{Na}_{8} \mathrm{H}\left[\alpha-\mathrm{PW}_{9} \mathrm{O}_{34}\right], \mathrm{Na}_{10}\left[\alpha-\mathrm{SiW}_{9} \mathrm{O}_{34}\right], \mathrm{Na}_{10}\left[\alpha-\mathrm{GeW}_{9} \mathrm{O}_{34}\right]$ and $\mathrm{Na}_{10} \mathrm{H}_{2} \mathrm{~W}_{12} \mathrm{O}_{42}$ were $8.19 \times 10^{-9}$, $6.07 \times 10^{-8}, 1.69 \times 10^{-8}$ and $3.22 \times 10^{-7} \mathrm{M} \cdot \mathrm{S}^{-1}$, respectively. The values for $K_{\text {cat }} \mathrm{H}_{2} \mathrm{O}_{2}$ of $\mathrm{Na}_{8} \mathrm{H}\left[\alpha-\mathrm{PW}_{9} \mathrm{O}_{34}\right]$, $\mathrm{Na}_{10}\left[\alpha-\mathrm{SiW}_{9} \mathrm{O}_{34}\right], \mathrm{Na}_{10}\left[\alpha-\mathrm{GeW}_{9} \mathrm{O}_{34}\right]$ and $\mathrm{Na}_{10} \mathrm{H}_{2} \mathrm{~W}_{12} \mathrm{O}_{42}$ were $9.73 \times 10^{-6} \mathrm{~S}^{-1}, 2.48 \times 10^{-5} \mathrm{~S}^{-1}, 1.58 \times 10^{-4} \mathrm{~S}^{-1}$ and $4.26 \times 10^{-5} \mathrm{~S}^{-1}$, respectively. The comparison of $K_{m}$ and $V_{\max }$ of peroxidase-like enzymes were listed in Table 1. It was found that $\mathrm{K}_{10} \mathrm{P}_{2} \mathrm{~W}_{18} \mathrm{Fe}_{4}\left(\mathrm{H}_{2} \mathrm{O}\right)_{2} \mathrm{O}_{68}$ had lower $K_{m}$ than other POMs-based peroxidases with OPD or $\mathrm{H}_{2} \mathrm{O}_{2}$ as 

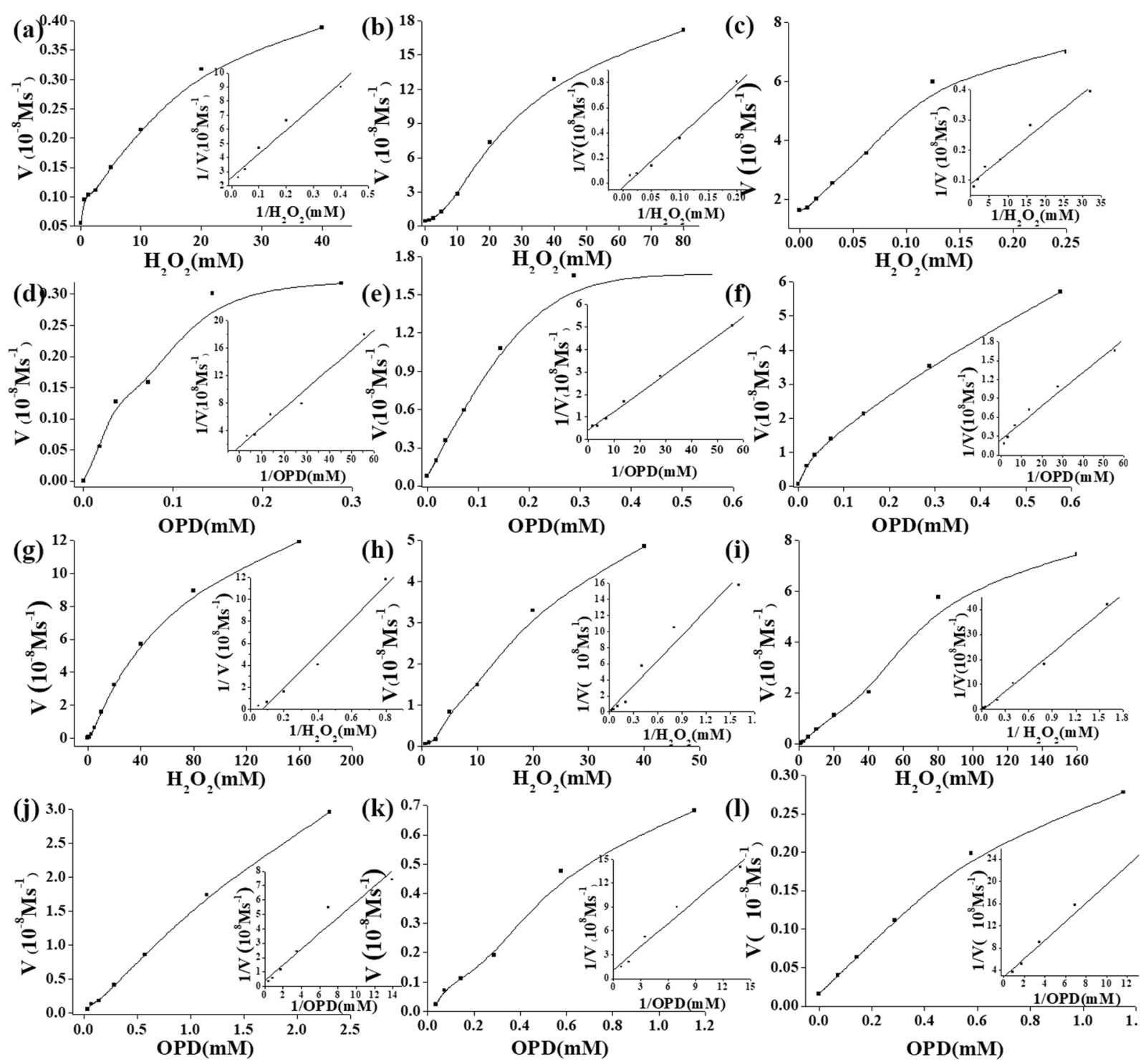

Figure 7. The steady-state kinetic assay and catalytic mechanism of peroxidase-like enzymes. (a,b) $\mathrm{K}_{10} \mathrm{P}_{2} \mathrm{~W}_{18} \mathrm{Fe}_{4}\left(\mathrm{H}_{2} \mathrm{O}\right)_{2} \mathrm{O}_{68},(\mathbf{c}, \mathbf{d}) \mathrm{H}_{3} \mathrm{PW}_{12} \mathrm{O}_{40},(\mathbf{a}, \mathbf{e}) \mathrm{Na}_{8} \mathrm{H}\left[\alpha-\mathrm{PW}_{9} \mathrm{O}_{34}\right],(\mathbf{b}, \mathbf{f}) \mathrm{Na}_{10}\left[\alpha-\mathrm{SiW}_{9} \mathrm{O}_{34}\right],(\mathbf{c}, \mathbf{g}) \mathrm{Na}_{10}[\alpha-$ $\left.\mathrm{GeW}_{9} \mathrm{O}_{34}\right]$ and $(\mathbf{d}, \mathbf{h}) \mathrm{Na}_{10} \mathrm{H}_{2} \mathrm{~W}_{12} \mathrm{O}_{42}$.

substrates. It suggests that $\mathrm{K}_{10} \mathrm{P}_{2} \mathrm{~W}_{18} \mathrm{Fe}_{4}\left(\mathrm{H}_{2} \mathrm{O}\right)_{2} \mathrm{O}_{68}$ might have a similar affinity for the surfaces of OPD with HRP. The mechanism of steady-state kinetics of $\mathrm{K}_{10} \mathrm{P}_{2} \mathrm{~W}_{18} \mathrm{Fe}_{4}\left(\mathrm{H}_{2} \mathrm{O}\right)_{2} \mathrm{O}_{68}$ were also investigated with TMB as substrates, as shown in Supplementary Fig. S8. The values for $K_{m}$ and $V_{\max } \mathrm{TMB}$ was $0.25 \mathrm{mM}$ and $2.42 \times 10^{-7} \mathrm{M} \cdot \mathrm{S}^{-1}$, respectively. The values for $K_{m}$ and $V_{\max } \mathrm{H}_{2} \mathrm{O}_{2}$ was $1.09 \mathrm{mM}$ and $1.02 \times 10^{-7} \mathrm{M} \cdot \mathrm{S}^{-1}$. It suggests that $\mathrm{K}_{10} \mathrm{P}_{2} \mathrm{~W}_{18} \mathrm{Fe}_{4}\left(\mathrm{H}_{2} \mathrm{O}\right)_{2} \mathrm{O}_{68}$ might have a similar affinity for the surfaces of TMB with HRP. The $K_{\text {cat }}$ of $\mathrm{K}_{10} \mathrm{P}_{2} \mathrm{~W}_{18} \mathrm{Fe}_{4}\left(\mathrm{H}_{2} \mathrm{O}\right)_{2} \mathrm{O}_{68}$ with $\mathrm{H}_{2} \mathrm{O}_{2}$ and TMB are $4.54 \times 10^{-2} \mathrm{~S}^{-1}$ and $8.82 \times 10^{-3} \mathrm{~S}^{-1}$. Comparing with the other organic-inorganic POM-based hybrids as shown in Table $\mathrm{S} 1$, the $\mathrm{K}_{10} \mathrm{P}_{2} \mathrm{~W}_{18} \mathrm{Fe}_{4}\left(\mathrm{H}_{2} \mathrm{O}\right)_{2} \mathrm{O}_{68}$ also show strong peroxidase activities with $\mathrm{TMB}$ as a substrate. It can be selected to construct new materials with organic groups or different nanomaterials.

The $K_{m}$ and $V_{\max }$ were obtained for oxidase-like enzymes, as shown in Fig. 8. With OPD as substrates, the values of $K_{m}$ OPD were $0.014,0.013,0.038,0.015$ and $0.015 \mathrm{mM}$ for $\mathrm{H}_{3} \mathrm{PMo}_{12} \mathrm{O}_{40}, \mathrm{H}_{4} \mathrm{SiMo}_{12} \mathrm{O}_{40}, \mathrm{Eu}_{3} \mathrm{PMo}_{12} \mathrm{O}_{40}$, $\mathrm{H}_{5} \mathrm{PMo}_{10} \mathrm{~V}_{2} \mathrm{O}_{40}$ and $\alpha-1,2,3,-\mathrm{K}_{6} \mathrm{H}\left[\mathrm{SiW}_{9} \mathrm{~V}_{3} \mathrm{O}_{34}\right]$. The $V_{\max } \mathrm{OPD}$ of $\mathrm{H}_{3} \mathrm{PMo}_{12} \mathrm{O}_{40}, \mathrm{H}_{4} \mathrm{SiMo}_{12} \mathrm{O}_{40}, \mathrm{Eu}_{3} \mathrm{PMo}_{12} \mathrm{O}_{40}$, $\mathrm{H}_{5} \mathrm{PMo}_{10} \mathrm{~V}_{2} \mathrm{O}_{40}$ and $\alpha-1,2,3,-\mathrm{K}_{6} \mathrm{H}\left[\mathrm{SiW}_{9} \mathrm{~V}_{3} \mathrm{O}_{34}\right]$ were $1.08 \times 10^{-9}, 6.19 \times 10^{-9}, 2.83 \times 10^{-9}, 2.64 \times 10^{-9}$ and $1.30 \times 10^{-8} \mathrm{M} \cdot \mathrm{S}^{-1}$, respectively. The $K_{\text {cat }} \mathrm{OPD}$ of $\mathrm{H}_{3} \mathrm{PMo}_{12} \mathrm{O}_{40}, \mathrm{H}_{4} \mathrm{SiMo}_{12} \mathrm{O}_{40}, \mathrm{Eu}_{3} \mathrm{PMo}_{12} \mathrm{O}_{40}, \mathrm{H}_{5} \mathrm{PMo}_{10} \mathrm{~V}_{2} \mathrm{O}_{40}$ and $\alpha-1,2,3-\mathrm{K}_{6} \mathrm{H}\left[\mathrm{SiW}_{9} \mathrm{~V}_{3} \mathrm{O}_{34}\right]$ were $4.32 \times 10^{-5}, 3.09 \times 10^{-4}, 5.66 \times 10^{-5}, 1.32 \times 10^{-4}$ and $1.73 \times 10^{-3} \mathrm{~S}^{-1}$, respectively. The comparison of $K_{m}$ and $V_{\max }$ with different substrates were shown in Table 2. The value results of $K_{m}$ OPD suggested that OPD have similar affinity for the surface of the oxidase-like POMs except the $\mathrm{Eu}_{3} \mathrm{PMo}_{12} \mathrm{O}_{40}$. $\alpha-1,2,3-\mathrm{K}_{6} \mathrm{H}\left[\mathrm{SiW}_{9} \mathrm{~V}_{3} \mathrm{O}_{34}\right]$ has the fastest catalytic rate than the other POMs. Among the saturated Keggin-type POMs, the counter ion $\mathrm{Eu}^{3+}$ maybe inhibit the poly anions interactions with the organic component. The $K_{m}$ and $V_{\max }$ were also obtained with TMB as substrate, as shown in Supplementary Fig. S9. The $K_{m}$ of oxidase-like enzymes was dramatically lower than natural enzyme HRP With TMB as substrates, the $K_{m}$ were $0.616,0.49,0.086$, 


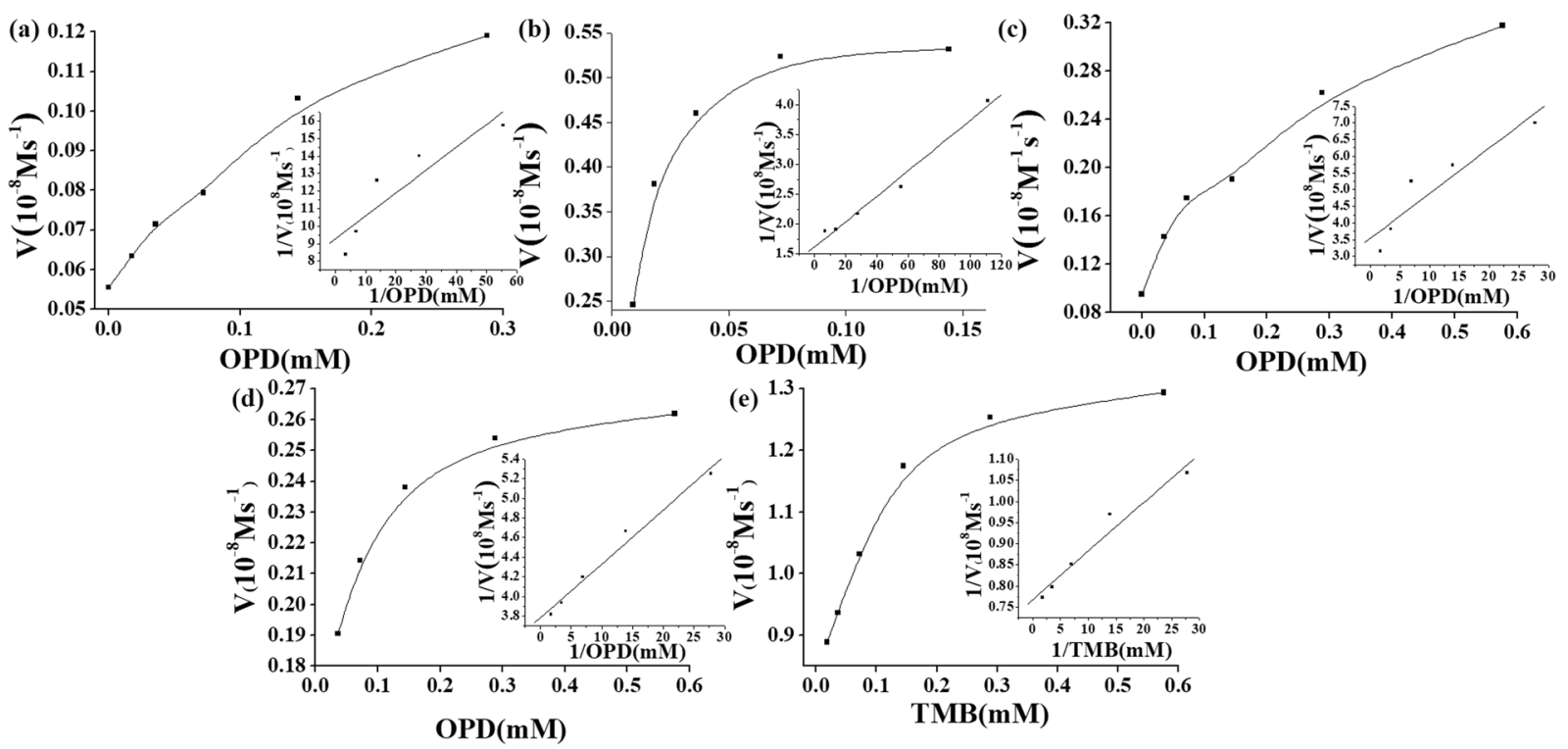

Figure 8. The steady-state kinetic assay and catalytic mechanism of oxidase-like enzymes. $(\mathbf{a}) \mathrm{H}_{3} \mathrm{PMo}_{12} \mathrm{O}_{40},(\mathbf{b})$ $\mathrm{H}_{4} \mathrm{SiMo}_{12} \mathrm{O}_{40}$, (c) $\mathrm{Eu}_{3} \mathrm{PMo}_{12} \mathrm{O}_{40}$, (d) $\mathrm{H}_{5} \mathrm{PMo}_{10} \mathrm{~V}_{2} \mathrm{O}_{40},(\mathbf{e}) \alpha-1,2,3-\mathrm{K}_{6} \mathrm{H}\left[\mathrm{SiW}_{9} \mathrm{~V}_{3} \mathrm{O}_{34}\right]$, (f) $\mathrm{H}_{6} \mathrm{P}_{2} \mathrm{Mo}_{18} \mathrm{O}_{62}$.

\begin{tabular}{|l|l|c|l|}
\hline Nanozymes & Substrate & $\boldsymbol{K}_{\boldsymbol{m}}(\mathbf{m M})$ & $\boldsymbol{V}_{\max }\left(\mathbf{M} \cdot \mathbf{S}^{-1}\right)$ \\
\hline $\mathrm{Na}_{8} \mathrm{H}\left[\alpha-\mathrm{PW}_{9} \mathrm{O}_{34}\right]$ & $\mathrm{OPD}$ & 1.39 & $6.14 \times 10^{-9}$ \\
\hline $\mathrm{Na}_{8} \mathrm{H}\left[\alpha-\mathrm{PW}_{9} \mathrm{O}_{34}\right]$ & $\mathrm{H}_{2} \mathrm{O}_{2}$ & 13.81 & $3.89 \times 10^{-9}$ \\
\hline $\mathrm{Na}_{10}\left[\alpha-\mathrm{SiW}_{9} \mathrm{O}_{34}\right]$ & $\mathrm{OPD}$ & 0.85 & $2.53 \times 10^{-8}$ \\
\hline $\mathrm{Na}_{10}\left[\alpha-\mathrm{SiW}_{9} \mathrm{O}_{34}\right]$ & $\mathrm{H}_{2} \mathrm{O}_{2}$ & 63.55 & $8.19 \times 10^{-9}$ \\
\hline $\mathrm{Na}_{10}\left[\alpha-\mathrm{GeW}_{9} \mathrm{O}_{34]}\right.$ & $\mathrm{OPD}$ & 0.61 & $8.79 \times 10^{-9}$ \\
\hline $\mathrm{Na}_{10}\left[\alpha-\mathrm{GeW}_{9} \mathrm{O}_{34}\right]$ & $\mathrm{H}_{2} \mathrm{O}_{2}$ & 44.05 & $6.07 \times 10^{-8}$ \\
\hline $\mathrm{Na}_{10} \mathrm{H}_{2} \mathrm{~W}_{12} \mathrm{O}_{42}$ & $\mathrm{OPD}$ & 0.2 & $3.65 \times 10^{-9}$ \\
\hline $\mathrm{Na}_{10} \mathrm{H}_{2} \mathrm{~W}_{12} \mathrm{O}_{42}$ & $\mathrm{H}_{2} \mathrm{O}_{2}$ & 132.03 & $1.69 \times 10^{-8}$ \\
\hline $\mathrm{K}_{10} \mathrm{P}_{2} \mathrm{~W}_{18} \mathrm{Fe}_{4}\left(\mathrm{H}_{2} \mathrm{O}\right)_{2} \mathrm{O}_{68}$ & $\mathrm{OPD}_{6}$ & 0.10 & $2.43 \times 10^{-8}$ \\
\hline $\mathrm{K}_{10} \mathrm{P}_{2} \mathrm{~W}_{18} \mathrm{Fe}_{4}\left(\mathrm{H}_{2} \mathrm{O}\right)_{2} \mathrm{O}_{68}$ & $\mathrm{H}_{2} \mathrm{O}_{2}$ & 0.11 & $3.22 \times 10^{-7}$ \\
\hline $\mathrm{H}_{3} \mathrm{PW}_{12} \mathrm{O}_{40}$ & $\mathrm{OPD}$ & 0.17 & $4.11 \times 10^{-8}$ \\
\hline $\mathrm{H}_{3} \mathrm{PW} \mathrm{P}_{12} \mathrm{O}_{40}$ & $\mathrm{H}_{2} \mathrm{O}_{2}$ & 6.62 & $1.13 \times 10^{-9}$ \\
\hline $\mathrm{HRP}$ & $\mathrm{OPD}$ & 0.59 & $4.65 \times 10^{-846}$ \\
\hline $\mathrm{HRP}$ & $\mathrm{H}_{2} \mathrm{O}_{2}$ & 0.34 & $9.48 \times 10^{-846}$ \\
\hline
\end{tabular}

Table 1. Comparison of the $K_{m}$ and $V_{\max }$ of peroxidase-like enzymes.

\begin{tabular}{|l|l|l|l|l|}
\hline Nanozymes & Substrate & $\boldsymbol{K}_{m}(\mathbf{m M})$ & $\boldsymbol{V}_{\max }\left(\mathbf{M} \cdot \mathbf{S}^{-1}\right)$ & Reference \\
\hline $\mathrm{H}_{3} \mathrm{PMo}_{12} \mathrm{O}_{40}$ & OPD & 0.014 & $1.08 \times 10^{-9}$ & This work \\
\hline $\mathrm{H}_{3} \mathrm{PMo}_{12} \mathrm{O}_{40}$ & TMB & 0.625 & $2.25 \times 10^{-7}$ & This work \\
\hline $\mathrm{H}_{4} \mathrm{SiMo}_{12} \mathrm{O}_{40}$ & OPD & 0.013 & $6.19 \times 10^{-9}$ & This work \\
\hline $\mathrm{H}_{4} \mathrm{SiMo}_{12} \mathrm{O}_{40}$ & TMB & 0.522 & $2.25 \times 10^{-7}$ & This work \\
\hline $\mathrm{Eu}_{3} \mathrm{PMo}_{12} \mathrm{O}_{40}$ & OPD & 0.038 & $2.83 \times 10^{-9}$ & This work \\
\hline Eu $_{3} \mathrm{PMo}_{12} \mathrm{O}_{40}$ & TMB & 0.086 & $2.60 \times 10^{-8}$ & This work \\
\hline $\mathrm{H}_{5} \mathrm{PMo}_{10} \mathrm{~V}_{2} \mathrm{O}_{40}$ & OPD & 0.015 & $2.64 \times 10^{-9}$ & This work \\
\hline $\mathrm{H}_{5} \mathrm{PMo}_{10} \mathrm{~V}_{2} \mathrm{O}_{40}$ & TMB & 0.553 & $2.30 \times 10^{-7}$ & This work \\
\hline $\mathrm{H}_{6} \mathrm{P}_{2} \mathrm{Mo}_{18} \mathrm{O}_{62}$ & TMB & 0.750 & $5.30 \times 10^{-7}$ & This work \\
\hline$\alpha-1,2,3-\mathrm{K}_{6} \mathrm{H}\left[\mathrm{SiW}_{9} \mathrm{~V}_{3} \mathrm{O}_{34}\right]$ & OPD & 0.015 & $1.30 \times 10^{-8}$ & This work \\
\hline$\alpha-1,2,3-\mathrm{K}_{6} \mathrm{H}\left[\mathrm{SiW}_{9} \mathrm{~V}_{3} \mathrm{O}_{34}\right]$ & TMB & 0.020 & $1.49 \times 10^{-8}$ & This work \\
\hline PMV-FA & TMB & 0.00041 & $4.70 \times 10^{-6}$ & 20 \\
\hline FAPMoV & TMB & $2.6 \times 10^{-3}$ & $1.33 \times 10^{-6}$ & 47 \\
\hline FAPMoV & TMB & $0.32 \times 10^{-3}$ & $1.46 \times 10^{-5}$ & 47 \\
\hline
\end{tabular}

Table 2. Comparison of the $K_{m}$ and $V_{\max }$ of oxidase-like enzymes. 

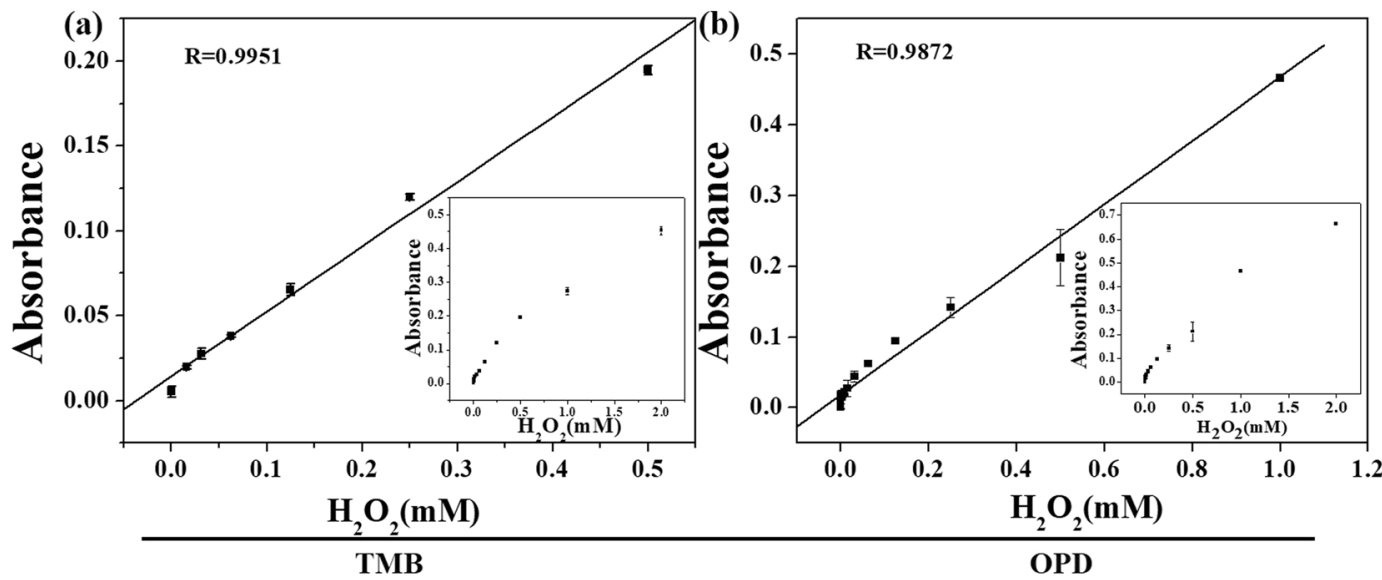

Figure 9. A does-response curve for $\mathrm{K}_{10} \mathrm{P}_{2} \mathrm{~W}_{18} \mathrm{Fe}_{4}\left(\mathrm{H}_{2} \mathrm{O}\right)_{2} \mathrm{O}_{68}$ depending of the absorbance at $450 \mathrm{~nm}$ with OPD as substrates and at $650 \mathrm{~nm}$ with TMB as substrates in the presence of diverse concentrations of $\mathrm{H}_{2} \mathrm{O}_{2}$. (a)TMB as substrates; (b) OPD as substrates.

0.55, 0.02, $0.75 \mathrm{mM}$ for $\mathrm{H}_{3} \mathrm{PMo}_{12} \mathrm{O}_{40}, \mathrm{H}_{4} \mathrm{SiMo}_{12} \mathrm{O}_{40}, \mathrm{Eu}_{3} \mathrm{PMo}_{12} \mathrm{O}_{40}, \mathrm{H}_{5} \mathrm{PMo}_{10} \mathrm{~V}_{2} \mathrm{O}_{40}, \alpha-1,2,3-\mathrm{K}_{6} \mathrm{H}\left[\mathrm{SiW}_{9} \mathrm{~V}_{3} \mathrm{O}_{34}\right]$ and $\mathrm{H}_{6} \mathrm{P}_{2} \mathrm{Mo}_{18} \mathrm{O}_{62}$. The $V_{\text {max }}$ of $\mathrm{H}_{3} \mathrm{PMo}_{12} \mathrm{O}_{40}, \mathrm{H}_{4} \mathrm{SiMo}_{12} \mathrm{O}_{40}, \mathrm{Eu}_{3} \mathrm{PMo}_{12} \mathrm{O}_{40}, \mathrm{H}_{5} \mathrm{PMo}_{10} \mathrm{~V}_{2} \mathrm{O}_{40}, \alpha-1,2,3-\mathrm{K}_{6} \mathrm{H}\left[\mathrm{SiW}_{9} \mathrm{~V}_{3} \mathrm{O}_{34}\right]$ and $\mathrm{H}_{6} \mathrm{P}_{2} \mathrm{Mo}_{18} \mathrm{O}_{62}$ were $2.25 \times 10^{-7}, 2.25 \times 10^{-7}, 2.60 \times 10^{-8}, 2.30 \times 10^{-7}, 1.49 \times 10^{-8}, 5.30 \times 10^{-7} \mathrm{M} \cdot \mathrm{S}^{-1}$, respectively. The $K_{c a t}$ of $\mathrm{H}_{3} \mathrm{PMo}_{12} \mathrm{O}_{40}, \mathrm{H}_{4} \mathrm{SiMo}_{12} \mathrm{O}_{40}, \mathrm{Eu}_{3} \mathrm{PMo}_{12} \mathrm{O}_{40}, \mathrm{H}_{5} \mathrm{PMo}_{10} \mathrm{~V}_{2} \mathrm{O}_{40}, \alpha-1,2,3-\mathrm{K}_{6} \mathrm{H}\left[\mathrm{SiW}_{9} \mathrm{~V}_{3} \mathrm{O}_{34}\right]$ and $\mathrm{H}_{6} \mathrm{P}_{2} \mathrm{Mo}_{18} \mathrm{O}_{62}$ were $9.00 \times 10^{-3}, 1.13 \times 10^{-2}, 5.20 \times 10^{-4}, 1.15 \times 10^{-2}, 1.98 \times 10^{-3}$ and $2.12 \times 10^{-7} \mathrm{~S}^{-1}$, respectively.

Detection of the reactive hydroxyl radicals $\cdot \mathrm{OH}$ production. The mechanism of peroxidase-like activity of POMs originates from their catalytic ability to the decomposition of $\mathrm{H}_{2} \mathrm{O}_{2}$ to produce hydroxyl radical $(\cdot \mathrm{OH})$. Terephthalic acid (TA) can capture $\cdot \mathrm{OH}$ to generate 2-hydroxy terephthalic acid (HTA) which can be detected by fluorescence method. So we chose TA as fluorescence probe to detect the generation of $\cdot \mathrm{OH}$. As show in Supplementary Fig. S10, the control groups (TA, TA with $\mathrm{H}_{2} \mathrm{O}_{2}$ and TA with POMs) did not show the significant intensity for HTA. Only in the presence of POMs and $\mathrm{H}_{2} \mathrm{O}_{2}$, the fluorescence can be remarkable found. This supported that the POMs can catalyze the $\mathrm{H}_{2} \mathrm{O}_{2}$ to generate $\cdot \mathrm{OH}$, then justify the peroxidase-like activities of POMs.

Calibration curve for $\mathrm{H}_{2} \mathrm{O}_{2}$ detection. Because the $\mathrm{K}_{10} \mathrm{P}_{2} \mathrm{~W}_{18} \mathrm{Fe}_{4}\left(\mathrm{H}_{2} \mathrm{O}\right)_{2} \mathrm{O}_{68}$ has the strongest the peroxidase mimetic activity, it can be used in the sensing for $\mathrm{H}_{2} \mathrm{O}_{2}$. Under optimum conditions, a colorimetric assay for the detection of hydrogen peroxide based on the peroxidase-like activity of $\mathrm{K}_{10} \mathrm{P}_{2} \mathrm{~W}_{18} \mathrm{Fe}_{4}\left(\mathrm{H}_{2} \mathrm{O}\right)_{2} \mathrm{O}_{68}$ has been established with TMB and OPD as substrates, as shown in Fig. 9. When the substrate was TMB, the linear detection range was estimated to be from 15 to $1000 \mu \mathrm{M}$ with correlation coefficients 0.9951 . The lower limit of detection (LOD) of $\mathrm{K}_{10} \mathrm{P}_{2} \mathrm{~W}_{18} \mathrm{Fe}_{4}\left(\mathrm{H}_{2} \mathrm{O}\right)_{2} \mathrm{O}_{68}$ was $10.43 \mu \mathrm{M}$. When the substrate was OPD, the correlation between the absorption value and $\mathrm{H}_{2} \mathrm{O}_{2}$ concentration were linear over the range of $15-500 \mu \mathrm{M}$ with correlation coefficients 0.9872 . The lower limit of detection (LOD) of $\mathrm{K}_{10} \mathrm{P}_{2} \mathrm{~W}_{18} \mathrm{Fe}_{4}\left(\mathrm{H}_{2} \mathrm{O}\right)_{2} \mathrm{O}_{68}$ was $8.86 \mu \mathrm{M}$. In addition, the analytical performance of $\mathrm{K}_{10} \mathrm{P}_{2} \mathrm{~W}_{18} \mathrm{Fe}_{4}\left(\mathrm{H}_{2} \mathrm{O}\right)_{2} \mathrm{O}_{68}$ as peroxidase mimics was compared with others reported POM, HRP and nanozymes, as summarized in Table 3. By comparing with other enzyme mimics, it revealed that the $\mathrm{K}_{10} \mathrm{P}_{2} \mathrm{~W}_{18} \mathrm{Fe}_{4}\left(\mathrm{H}_{2} \mathrm{O}\right)_{2} \mathrm{O}_{68}$ sensor has wider linear range.

\section{Conclusion}

In conclusion, the structures, the hybrid atoms, the coordination atoms, the substituted metal atoms are the effect factors for their enzyme mimic activities. The polyoxomolybdates $\left(\mathrm{H}_{3} \mathrm{PMo}_{12} \mathrm{O}_{40}, \mathrm{H}_{4} \mathrm{SiMo}_{12} \mathrm{O}_{40}\right.$ and $\left.\mathrm{Eu}_{3} \mathrm{PMo}_{12} \mathrm{O}_{40}\right)$ have shown oxidase-like enzymes activities, while the polyoxotungstates shows peroxidase mimic activities. The substituted metals improved the enzyme mimic activities of POMs, which proved in $\mathrm{H}_{5} \mathrm{PMo}_{10} \mathrm{~V}_{2} \mathrm{O}_{40}$, $\alpha-1,2,3-\mathrm{K}_{6} \mathrm{H}\left[\mathrm{SiW}_{9} \mathrm{~V}_{3} \mathrm{O}_{34}\right]$ and $\mathrm{K}_{10} \mathrm{P}_{2} \mathrm{~W}_{18} \mathrm{Fe}_{4}\left(\mathrm{H}_{2} \mathrm{O}\right)_{2} \mathrm{O}_{68}$. The affinity of POM with substrate is another important factor on their enzyme mimic activities. For example, the $\mathrm{Na}_{10} \mathrm{H}_{2} \mathrm{~W}_{12} \mathrm{O}_{42}, \mathrm{Na}{ }_{8} \mathrm{H}\left[\alpha-\mathrm{PW}_{9} \mathrm{O}_{34}\right], \mathrm{Na}_{10}\left[\alpha-\mathrm{SiW}_{9} \mathrm{O}_{34}\right]$ and $\mathrm{Na}_{10}\left[\alpha-\mathrm{GeW}_{9} \mathrm{O}_{34}\right]$ possessed peroxidase-like activities only with OPD as the substrates. $\mathrm{pH}$ condition is the key impact factor not only in the stability of POM but also the enzymes activities of them. The lacunary-Keggin type POMs, $\mathrm{Na}_{10}\left[\alpha-\mathrm{GeW}_{9} \mathrm{O}_{34}\right], \mathrm{Na}_{8} \mathrm{H}\left[\alpha-\mathrm{PW}_{9} \mathrm{O}_{34}\right]$ and $\mathrm{Na}_{10}\left[\alpha-\mathrm{SiW}_{9} \mathrm{O}_{34}\right]$ were firstly found to own strong catalytic activities under alkaline conditions. Interesting, $\mathrm{K}_{10} \mathrm{P}_{2} \mathrm{~W}_{18} \mathrm{Fe}_{4}\left(\mathrm{H}_{2} \mathrm{O}\right)_{2} \mathrm{O}_{68}$ showed the highest catalytic activities among the POMs. In the future, the further analysis the inorganic systems and functionalization of metal-substituted polyoxotungstates will be expected to have a potential application in biotechnology, clinical diagnosis and other industry to substitute natural enzymes.

\section{Experimental}

Chemicals and materials. All the chemicals used were of analysis and graded without further purification. OPD was purchased from Tianjin Guangfu Fine Chemical Research Institute (Tianjin, China). TMB was obtained from (Tokyo, Japan). $\mathrm{H}_{3} \mathrm{PW}_{12} \mathrm{O}_{40}, \mathrm{H}_{4} \mathrm{SiW}_{12} \mathrm{O}_{40}$ and $\mathrm{H}_{3} \mathrm{PMo}_{12} \mathrm{O}_{40}$ and Hydrogen peroxide $\left(\mathrm{H}_{2} \mathrm{O}_{2}, 30 \%\right)$ were purchased from Beijing Chemical Works (Beijing, China). The water used in the experiments was purified. 


\begin{tabular}{|c|c|c|c|c|}
\hline Nanozymes & Linear Range & Limit of Detection & Time & Reference \\
\hline $\mathrm{K}_{10} \mathrm{P}_{2} \mathrm{~W}_{18} \mathrm{Fe}_{4}\left(\mathrm{H}_{2} \mathrm{O}\right)_{2} \mathrm{O}_{68}$ & $15-1000 \mu \mathrm{M}$ & $10.43 \mu \mathrm{M}$ & $5 \mathrm{~min}$ & This work $^{\mathrm{a}}$ \\
\hline $\mathrm{K}_{10} \mathrm{P}_{2} \mathrm{~W}_{18} \mathrm{Fe}_{4}\left(\mathrm{H}_{2} \mathrm{O}\right)_{2} \mathrm{O}_{68}$ & $15-500 \mu \mathrm{M}$ & $8.86 \mu \mathrm{M}$ & $5 \mathrm{~min}$ & This work $^{\mathrm{k}}$ \\
\hline $\mathrm{Cu}_{6}(\mathrm{Trz})_{10}\left(\mathrm{H}_{2} \mathrm{O}\right)_{4}\left[\mathrm{H}_{2} \mathrm{SiW}_{12} \mathrm{O}_{40}\right]$ & $10-60 \mu \mathrm{M}$ & $1.37 \mu \mathrm{M}$ & $1 \mathrm{~min}$ & 32 \\
\hline $\mathrm{Na}_{4} \mathrm{H}_{2}\left[\mathrm{Cu}_{4}(\mathrm{im})_{14}\right]\left[\mathrm{Cu}_{3}\left(\mathrm{H}_{2} \mathrm{O}\right)_{3}\left(\mathrm{BiW}_{9} \mathrm{O}_{33}\right)_{2}\right]$ & $1-50 \mu \mathrm{M}$ & $0.12 \mu \mathrm{M}$ & $2 \mathrm{~min}$ & 28 \\
\hline $\mathrm{Na}_{4} \mathrm{H}_{2}\left[\mathrm{Cu}_{4}(\mathrm{im})_{14}\right]\left[\mathrm{Cu}_{3}\left(\mathrm{H}_{2} \mathrm{O}\right)_{3}\left(\mathrm{SbW}_{9} \mathrm{O}_{33}\right)_{2}\right]$ & $1-50 \mu \mathrm{M}$ & $0.12 \mu \mathrm{M}$ & $2 \mathrm{~min}$ & 28 \\
\hline $\mathrm{FA}-\mathrm{Fe}_{2} \mathrm{SiW}_{10}$ & $0.13-67 \mu \mathrm{M}$ & $0.13 \mu \mathrm{M}$ & $1 \mathrm{~min}$ & 22 \\
\hline $\mathrm{FF} @ \mathrm{PW}_{12}$ & $1-75 \mu \mathrm{M}$ & $0.11 \mu \mathrm{M}$ & $10 \mathrm{~min}$ & 27 \\
\hline $\mathrm{Na}_{4}\left(\mathrm{NH}_{4}\right)_{14}\left[\mathrm{Zr}_{4} \mathrm{O}_{6}(\mathrm{OAc})_{2}\left(\mathrm{P}_{2} \mathrm{~W}_{16} \mathrm{O}_{59}\right)_{2}\right] \cdot 51 \mathrm{H}_{2} \mathrm{O}$ & $100-1000 \mu \mathrm{M}$ & $100 \mu \mathrm{M}$ & $90 \mathrm{~min}$ & 23 \\
\hline $\mathrm{H}_{4} \mathrm{SiW}_{12} \mathrm{O}_{40}$ & $1-20 \mu \mathrm{M}$ & $0.4 \mu \mathrm{M}$ & $5 \mathrm{~min}$ & 19 \\
\hline $\mathrm{H}_{3} \mathrm{PW}_{12} \mathrm{O}_{40}$ & $0.1-67 \mu \mathrm{M}$ & $0.13 \mu \mathrm{M}$ & $10 \mathrm{~min}$ & 21 \\
\hline HRP & $1-60 \mu \mathrm{M}$ & $1 \mu \mathrm{M}$ & - & 48 \\
\hline $\mathrm{Fe}_{3} \mathrm{O}_{4} \mathrm{MNPs}$ & $1-100 \mu \mathrm{M}$ & $0.5 \mu \mathrm{M}$ & - & 49 \\
\hline
\end{tabular}

Table 3. Comparison of different nanozymes for the detection of $\mathrm{H}_{2} \mathrm{O}_{2} \cdot{ }^{\mathrm{a}} \mathrm{TMB}$ as the substrate; ${ }^{\mathrm{b}} \mathrm{OPD}$ as the substrate.

The POMs mimetic enzymes were characterized by IR and UV-vis spectrum. The UV-vis spectrum was recorded in the range of 200-600 nm on UV-Vis spectrophotometer (Puxi Inc., Beijing, China). Fourier-transform infrared spectrum (FT-IR) was collected in the range of $4000-400 \mathrm{~cm}^{-1}$ on an Alpha Centauri FT/IR spectrophotometer (Shizumi, Tokyo) using KBr pellets.

Synthesis of polyoxometalates. The 18 polyoxometalates including Keggin $\left(\mathrm{H}_{3} \mathrm{PW}_{12} \mathrm{O}_{40}\right.$, $\left.\mathrm{H}_{4} \mathrm{SiW}_{12} \mathrm{O}_{40}, \mathrm{H}_{4} \mathrm{GeW}_{12} \mathrm{O}_{40}, \mathrm{~K}_{4} \mathrm{GeW}_{12} \mathrm{O}_{40}, \mathrm{H}_{4} \mathrm{SiMo}_{12} \mathrm{O}_{40}, \mathrm{H}_{3} \mathrm{PMo}_{12} \mathrm{O}_{40}, \mathrm{Eu}_{3} \mathrm{PMo}_{12} \mathrm{O}_{40}\right)$, Dawson $\left(\mathrm{H}_{6} \mathrm{P}_{2} \mathrm{Mo}_{18} \mathrm{O}_{62}\right.$, $\left.\alpha-\left(\mathrm{NH}_{4}\right)_{6} \mathrm{P}_{2} \mathrm{~W}_{18} \mathrm{O}_{62}, \alpha-\mathrm{K}_{6} \mathrm{P}_{2} \mathrm{~W}_{18} \mathrm{O}_{62} \cdot 14 \mathrm{H}_{2} \mathrm{O}\right)$, lacunary-Keggin $\left(\mathrm{Na}_{10}\left[\alpha-\mathrm{GeW}_{9} \mathrm{O}_{34}\right], \mathrm{Na}_{8} \mathrm{H}\left[\alpha-\mathrm{PW}_{9} \mathrm{O}_{34}\right]\right.$, $\left.\mathrm{Na}_{10}\left[\alpha-\mathrm{SiW}_{9} \mathrm{O}_{34}\right], \mathrm{K}_{8}\left[\gamma-\mathrm{SiW}_{10} \mathrm{O}_{36}\right]\right)$ and the transition-metal substituted-type $\left(\alpha-1,2,3-\mathrm{K}_{6} \mathrm{H}\left[\mathrm{SiW}_{9} \mathrm{~V}_{3} \mathrm{O}_{34}\right]\right.$, $\mathrm{H}_{5} \mathrm{PMo}_{10} \mathrm{~V}_{2} \mathrm{O}_{40}$, Wells-Dawson $\left(\mathrm{K}_{10} \mathrm{P}_{2} \mathrm{~W}_{18} \mathrm{Fe}_{4}\left(\mathrm{H}_{2} \mathrm{O}\right)_{2} \mathrm{O}_{68}\right)$ investigated in this study were synthesized according to the literature ${ }^{36-43}$ or provide by prof. Yangguang $\mathrm{Li}$.

Enzyme mimetic activities of POMs. The enzyme mimetic activities of POMs were determined spectrophotometrically by measuring the formation of DAB from OPD at $450 \mathrm{~nm}\left(\varepsilon=2.1 \times 10^{4} \mathrm{mM}^{-1} \mathrm{~cm}^{-1}\right)^{44}$ or $\mathrm{TMB}^{+}$from TMB at $650 \mathrm{~nm}\left(\varepsilon=3.9 \times 10^{4} \mathrm{mM}^{-1} \mathrm{~cm}^{-1}\right)^{45}$ using UV-vis spectrophotometer in a $1 \mathrm{~cm}$ cuvette. Typically, the $480 \mu \mathrm{L}$ of TMB (1.5 mM in ethanol) or OPD solution (3.6 mM in water) was added into $2400 \mu \mathrm{L}$ different buffer solutions $\left(\mathrm{NaH}_{2} \mathrm{PO}_{4}\right.$-citrate or Tris- $\left.\mathrm{HCl}\right)$, followed by the addition of $60 \mu \mathrm{L}$ of POMs $(10 \mathrm{mM})$ and $60 \mu \mathrm{L}$ of hydrogen peroxide $\left(\mathrm{H}_{2} \mathrm{O}_{2}, 10 \mathrm{M}\right)$. The mixed solution was incubated at room temperature. The oxidases activities of POMs $(10 \mathrm{mM})$ were used under the same identical reaction conditions with the absence of $\mathrm{H}_{2} \mathrm{O}_{2}$.

$\mathrm{pH}$ measurements. The activities of the POMs at different $\mathrm{pH}$ values were performed using the same condition as above, except two different buffer compositions for the different $\mathrm{pH}$ ranges were employed. The reaction was carried out $200 \mu \mathrm{M}$ POMs to which TMB $(240 \mu \mathrm{M})$ or OPD $(576 \mu \mathrm{M})$ and $\mathrm{H}_{2} \mathrm{O}_{2}(200 \mathrm{mM})$ were added. Between $\mathrm{pH} 2.5$ to 7, $0.2 \mathrm{mM}$ of $\mathrm{Na}_{2} \mathrm{HPO}_{4}$-citrate buffer was used; for $\mathrm{pH} 7-10,0.1 \mathrm{mM}$ of Tris-HCl buffer was used. The $\mathrm{pH}$ of the different buffers was adjusted using a $\mathrm{pH}$ meter (PHS-25 pH meter, Shanghai INESA Scientific Instrument Co., China).

Determination of kinetic parameters. The steady-state kinetics of POM-peroxidase were conducted by varying the concentrations of $\mathrm{H}_{2} \mathrm{O}_{2}(0-200 \mathrm{mM})$, or OPD/TMB $(0-576 \mu \mathrm{M} / 0-240 \mu \mathrm{M})$ one at a time. The reaction was carried out in $0.2 \mathrm{mM} \mathrm{Na}_{2} \mathrm{HPO}_{4}$-citrate buffer and $0.1 \mathrm{mM}$ Tris- $\mathrm{HCl}$ (at the optimum $\mathrm{pH}$ ) and monitored spectrophotometrically by $300 \mathrm{~s}$ using a $1 \mathrm{~cm}$ cuvette. The kinetic curves were adjusted to the Michaelis-Menten model and linear weaver-Burk linearizations were performed using origin 7.0 software. The apparent kinetic parameters were calculated based on the equation $v=V_{\max } \times[\mathrm{S}] /\left(K_{m}+[\mathrm{S}]\right)$, where $v$ is the initial velocity, $V_{\max }$ is the maximal reaction velocity, [S] is the concentration of substrate, and $K_{m}$ is the Michaelis constant.

Detection of the reactive hydroxyl radicals $\cdot \mathrm{OH}$ production. The hydroxyl radicals $(\cdot \mathrm{OH})$ production was measured by fluorescence method. The terephthalic acid was used as a fluorescence probe for detection the .OH from the $\mathrm{H}_{2} \mathrm{O}_{2}$ for $\mathrm{Na}_{10}\left[\alpha-\mathrm{GeW}_{9} \mathrm{O}_{34}\right], \mathrm{Na}_{8} \mathrm{H}\left[\alpha-\mathrm{PW}_{9} \mathrm{O}_{34}\right], \mathrm{Na}_{10}\left[\alpha-\mathrm{SiW}_{9} \mathrm{O}_{34}\right]$ and $\mathrm{K}_{10} \mathrm{P}_{2} \mathrm{~W}_{18} \mathrm{Fe}_{4}\left(\mathrm{H}_{2} \mathrm{O}\right)_{2} \mathrm{O}_{68}$ as catalysts. $75 \mu \mathrm{L}$ of $25 \mathrm{mM}$ TA in $\mathrm{NaOH}(\mathrm{pH}=13)$ solution was added into the $3 \mathrm{~mL}$ of $\mathrm{PBS}(\mathrm{pH}=7.4)$ containing $100 \mathrm{mM} \mathrm{H}_{2} \mathrm{O}_{2}$ and/or $1 \mathrm{mM}$ POMs. After $24 \mathrm{~h}$ incubation in the dark, the resulting solution was detected. The fluorescence spectra were obtained with excitation wavelength of $315 \mathrm{~nm}$ and the emission spectra were recorded in the wavelength of $425 \mathrm{~nm}$. 
Detection of $\mathrm{H}_{2} \mathrm{O}_{2}$. The detection of $\mathrm{H}_{2} \mathrm{O}_{2}$ was performed according to the following steps: $480 \mu \mathrm{L}$ of OPD solution $(576 \mu \mathrm{M})$ or TMB solution $(240 \mu \mathrm{M}), 60 \mu \mathrm{L}$ of POMs $(100 \mu \mathrm{M})$ and $60 \mu \mathrm{L} \mathrm{H}_{2} \mathrm{O}_{2}(200 \mathrm{mM})$ with various concentrations were added into $2400 \mu \mathrm{L}$ of buffer solution, and the total volume of the mixed solution was $3 \mathrm{~mL}$. After reacting 5 min under the optimum conditions, then the UV-Vis spectrophotometer was used to record the absorbance at $450 \mathrm{~nm}$ for OPD and $650 \mathrm{~nm}$ for TMB.

Received: 4 April 2019; Accepted: 12 September 2019;

Published online: 16 October 2019

\section{References}

1. Mozhaev, V. V., Sergeeva, M. V., Belova, A. B. \& Khmelnitsky, Y. L. Multipoint attachment to a support protects enzyme from inactivation by organic solvents: $\alpha$-chymotrypsin in aqueous solutions of alcohols and diols. Biotechnol. Bioeng. 35, 653-659 (1990).

2. Burton, S. G., Cowan, D. A. \& Woodley, J. M. The search for the ideal biocatalyst. Nat. Biotechnol. 20, 37-45 (2002).

3. Rreslow, R. \& Overman, L. E. "Artificial enzyme" combining a metal catalytic group and a hydrophobic binding cavity. J. Am. Chem. Soc. 92, 1075-1077 (1970).

4. R. Breslow, Artificial enzymes, Wiley-VCH, Weinheim. (2005).

5. Raynal, M., Ballester, P., Vidal-Ferran, A. \& Van Leeuwen, P. W. N. M. Supramolecular catalysis. Part 1: non-covalent interactions as a tool for building and modifying homogeneous catalysts. Chem. Soc. Rev. 43, 1734-1787 (2014).

6. Aiba, Y., Sumaoka, J. \& Komiyama, M. Artificial DNA cutters for DNA manipulation and genome engineering. Chem. Soc. Rev. 40, 5657-5668 (2011).

7. Gao, L. Z. et al. Intrinsic peroxidase-like activity of ferromagnetic nanoparticles. Nat. Nanotechnol. 2, 577-583 (2007).

8. Wei, H. \& Wang, E. K. Nanomaterials with enzyme-like characteristics (nanozymes): next-generation artificial enzymes. Chem. Soc. Rev. 42, 6060-6093 (2013).

9. Wei, H. \& Wang, E. K. $\mathrm{Fe}_{3} \mathrm{O}_{4}$ magnetic nanoparticles as peroxidase mimetics and their applications in $\mathrm{H}_{2} \mathrm{O}_{2}$ and glucose detection. Anal. Chem. 80, 2250-2254 (2008).

10. Kuah, E., Toh, S., Yee, J., Ma, Q. \& Gao, Z. Q. Enzyme mimics: advances and applications. Chem. Eur. J. 22, 8404-8430 (2016).

11. Komkova, M. A., Karyakina, E. E. \& Karyakin, A. A. Catalytically synthesized prussian blue nanoparticles defeating natural enzyme peroxidase. J. Am. Chem. Soc. 140, 11302-11307 (2018).

12. Long, D. L., Tsunashima, R. \& Cronin, L. Polyoxometalates: building blocks for functional nanoscale systems. Angew. Chem. Int. Edit 49, 1736-1758 (2010).

13. Pope, M. T. \& Müller, A. Polyoxometalate chemistry: an old field with new dimensions in several disciplines. Angew. Chem. Int. Edit. 30, 34-48 (1991).

14. Ma, Y. Y. et al. Highly efficient hydrogen evolution from seawater by a low-cost and stable CoMoP@C electrocatalyst superior to Pt/C. Energ. Environ. Sci. 10, 788-798 (2017).

15. Li, J. S. et al. Coupled molybdenum carbide and reduced graphene oxide electrocatalysts for efficient hydrogen evolution. Nat. Commun. 7, 11204 (2016).

16. Wang, S. S. \& Guo, Y. Y. Recent advance in polyoxometalate-catalyzed reactions. Chem. Rev. 115, 4893-4962 (2015).

17. Long, D. L., Tsunashima, R. \& Cronin, L. Polyoxometalates: building blocks for functional nanoscale systems. Angew. Chem. 122, 1780-1803 (2010).

18. Mizuno, N., Yamaguchi, K. \& Kamata, K. Epoxidation of olefins with hydrogen peroxide catalyzed by polyoxometalates. Coord. Chem. Rev. 249, 1944-1956 (2005).

19. Liu, S. et al. Fast and sensitive colorimetric detection of $\mathrm{H}_{2} \mathrm{O}_{2}$ and glucose: a strategy based on polyoxometalate clusters. Chempluschem. 77, 541-544 (2012).

20. Wang, J. J., Mi, X. G., Guan, H. Y., Wang, X. H. \& Wu, Y. Assembly of folate-polyoxometalate hybrid spheres for colormetric immunoassay like oxidase. Chem. Commun. 47, 2940-2942 (2011).

21. Wang, J. J., Han, D. X., Wang, X. H., Qi, B. \& Zhao, M. S. Polyoxometalates as peroxidase mimetics and their applications in $\mathrm{H}_{2} \mathrm{O}_{2}$ and glucose detection. Biosens. Bioelectron. 36, 18-21 (2012).

22. Sun, Z. et al. Fabrication of inorganic-organic hybrid based on polyoxometalates $\mathrm{SiW}_{10} \mathrm{Fe}_{2}$ and folate as peroxidases for colormetric immunoassay of cancer cells. Chinese Chem. Lett. 24, 76-78 (2013).

23. Li, D. et al. Modification of tetranuclear zirconium-substituted polyoxometalates- syntheses, structures, and peroxidase-like catalytic activities. Chem. Eur. J. 24, 1926-1934 (2013).

24. Duan, X. X. et al. Fabrication of metal-substituted polyoxometalates for colorimetric detection of dopamine and ractopamine. Materials. 11, 674-684 (2018)

25. Zeb, A. et al. Intrinsic peroxidase-like activity and enhanced photo-Fenton reactivity of iron-substituted polyoxometalate nanostructures. Dalton Trans. 47, 7344-7352 (2018).

26. She, S. et al. Aliphatic organoimido derivatives of polyoxometalates containing a bioactive ligand. Chem. Eur. J. 51, 16987-16994 (2014).

27. Ma, Z. et al. Effective synergistic effect of dipeptide-polyoxometalate-graphene oxide ternary hybrid materials on peroxidase-like mimics with enhanced performance. ACS Appl. Mater. Interfaces. 39, 22036-22045 (2015).

28. Chai, D. F. et al. Synergistic effect of sandwich polyoxometalates and copper-imidazole complexes for enhancing the peroxidase-like activity. RSC Adv. 5, 78771-78779 (2015).

29. Li, X. et al. Keggin polyoxometalates based hybrid compounds containing helix/nanocages for colormetric biosensing. J. Solid State Chem. 265, 372-380 (2018).

30. Narkhede, N., Uttam, B. \& Rao, C. P. Inorganic-organic covalent hybrid of polyoxometalate-calixarene: Synthesis, characterization and enzyme activity. Inorg. Chim. Acta. 483, 337-342 (2018).

31. Chen, K. et al. Improved peroxidase-mimic property: Sustainable, high efficiency interfacial catalysis with $\mathrm{H}_{2} \mathrm{O}_{2}$ on the surface of vesicles of hexavanadate-organic hybrid surfactants. Nano Res. 3, 1313-1321 (2018).

32. Zhou, E. L. et al. A stable polyoxometalate-pillared metal-organic framework for proton-conducting and colormetric biosensing. Chem. Eur. J. 21, 11894-11898 (2015).

33. Li, X. et al. Synthesis, structure and effective peroxidase-like activity of a stable polyoxometalate-pillared metal-organic framework with multinuclear cycles. Polyhedron 151, 206-212 (2018).

34. Zhao, J. W. et al. Lanthanide-Connecting and Lone-Electron-Pair Active Trigonal-Pyramidal-AsO $\mathrm{O}_{3}$ Inducing Nanosized Poly(polyoxotungstate) Aggregates and Their Anticancer Activities. Sci. Rep. 6, 26406-26418 (2016).

35. Tian, R., Zhang, B. Y., Zhao, M. M., Ma, Q. \& Qi, Y. F. Polyoxometalates as promising enzyme mimics for the sensitive detection of hydrogen peroxide by fluorometric method. Talanta. 188, 332-338 (2018).

36. Rocchiccioli-Deltcheff, C., Fournier, M., Franck, R. \& Thouvenot, R. Chemlnform abstract: vibrational investigations of polyoxometalates.2. evidence for anion-anion interactions in molybdenun(VI) compounds related to the keggin structure. Inorg. Chem. 22, 207 (1993). 
37. Romanelli, G. P. et al. Silicagel-supported $\mathrm{H}_{6} \mathrm{P}_{2} \mathrm{~W}_{18} \mathrm{O}_{62} \cdot 24 \mathrm{H}_{2} \mathrm{O}$ : a reusable catalyst to prepare diphenylmethyl (DPM) ethers. ARKIVOC 1, 1 (2017).

38. Tézé, A., Hervé, G., Finke, R. G. \& Lyon, D. K. $\alpha$-, $\beta$-, and $\gamma$-Dodecatungstosilicic acids: isomers and related lacunary compounds. Inorganic Syntheses. 27, 85-96 (2007).

39. Allmann, R. Die Struktur des Ammoniumparawolframates $\left(\mathrm{NH}_{4}\right)_{10}\left[\mathrm{H}_{2} \mathrm{~W}_{12} \mathrm{O}_{42}\right] \cdot 10 \mathrm{H}_{2} \mathrm{O}$. Acta. Cryst. B27, 1393-1404 (1971).

40. Domaille, P. J. 1- and 2-dimensinal tungsten-183 and vanadium-51 NMR characterization of isopolymetalates and heteropolymetalates. J. Am. Chem. Soc. 106, 7677-7687 (1984).

41. Tang, Y. \& Zhang, J. Direct oxidation of benzene to phenol catalyzed by vanadium substituted heteropolymolybdic acid. Transit. Metal Chem. 31, 299-305 (2006).

42. Finke, R. G., Droege, M. W. \& Domaille, P. J. Trivacant heteropolytungstate derivative. 3 rational syntheses, characterization, twodimensional ${ }^{183} \mathrm{~W}$ NMR, and properties of $\mathrm{P}_{2} \mathrm{~W}_{18} \mathrm{M}_{4}\left(\mathrm{H}_{2} \mathrm{O}\right)_{2} \mathrm{O}_{68}{ }^{10-}$ and $\mathrm{P}_{4} \mathrm{~W}_{30} \mathrm{M}_{4}\left(\mathrm{H}_{2} \mathrm{O}\right)_{2} \mathrm{O}_{112}{ }^{16-}(\mathrm{M}=\mathrm{Co}, \mathrm{Cu}$, Zn). Inorg. Chem. 6, 3886-3896 (1987).

43. Barats, D., Leitus, G., Biro, R. P., Shimon, L. J. W. \& Neurmann, R. A stable 'end-on' iron(III)-hydroperoxo complex in water derived from a multi-iron(II)-substituted polyoxometalate and molecular oxygen. Angew. Chem. Int. Ed. 47, 9908-9912 (2008).

44. Tyagi, N. \& Mathur, P. Iron (III) complexes of bis (benzimidazole-2-yl) methyl thiophene-2,5-dicarboxamide: synthesis, spectral and oxidation of o-phenylenediamine. Spectrochim. Acta. A. 96, 759-767 (2012).

45. Gao, Z. Q., Xu, M. D., Hou, L., Chen, G. N. \& Tang, D. P. Irregular-shaped platinum nanoparticles as peroxidase mimics for highly efficient colorimetric immunoassay. Anal. Chim. Acta. 776, 79-86 (2013).

46. Liu, X. et al. BSA-templated $\mathrm{MnO}_{2}$ nanoparticles as both peroxidase and oxidase mimics. Analyst. 137, 4552-4558 (2012).

47. Ji, Y. et al. Inorganic-bimolecular hybrids based on polyoxometalates: intrinsic oxidase catalytic activity and their application to cancer immunoassay. Sens. Actuators B. 208, 497-504 (2015)

48. Edgar, P. \& Yona, K. A Simple Colorimetric Method for the measurement of hydrgen peroxide produced by cells in culture. J. Immunol. Methods. 38, 161-170 (1980).

49. Kim, M. I., Shim, J., Li, T., Lee, J. \& Park, H. G. Fabrication of nanoporous nanocomposites entrapping $\mathrm{Fe}_{3} \mathrm{O}_{4}$ magnetic nanoparticles and oxidases for colorimetric biosensing. Chem. Eur. J. 17, 10700-10707 (2011).

\section{Acknowledgements}

This work was financially supported by NSFC (81402719) and Norman Bethune Program of Jilin University (2015228). We highly appreciate Prof. Yangguang Li from the Institute of Polyoxometalate Chemistry, Department of Chemistry, Northeast Normal University for the POMs. The open project of the CAS Key Laboratory for Biomedical Effects of Nanomaterials and Nanosafety (NKSF201801).

\section{Author contributions}

Y.Q. conceived and designed the experiment, B.Z. performed the experiments and analyzed the data. Y.Q. contributed reagents/materials/analysis tools, B.Z., M.Z., R.T., B.C., H.Z., C.Z. and C.W. wrote the paper. All authors reviewed the manuscript.

\section{Competing interests}

The authors declare no competing interests.

\section{Additional information}

Supplementary information is available for this paper at https://doi.org/10.1038/s41598-019-50539-9.

Correspondence and requests for materials should be addressed to Y.Q.

Reprints and permissions information is available at www.nature.com/reprints.

Publisher's note Springer Nature remains neutral with regard to jurisdictional claims in published maps and institutional affiliations.

(c) (i) Open Access This article is licensed under a Creative Commons Attribution 4.0 International License, which permits use, sharing, adaptation, distribution and reproduction in any medium or format, as long as you give appropriate credit to the original author(s) and the source, provide a link to the Creative Commons license, and indicate if changes were made. The images or other third party material in this article are included in the article's Creative Commons license, unless indicated otherwise in a credit line to the material. If material is not included in the article's Creative Commons license and your intended use is not permitted by statutory regulation or exceeds the permitted use, you will need to obtain permission directly from the copyright holder. To view a copy of this license, visit http://creativecommons.org/licenses/by/4.0/.

(C) The Author(s) 2019 